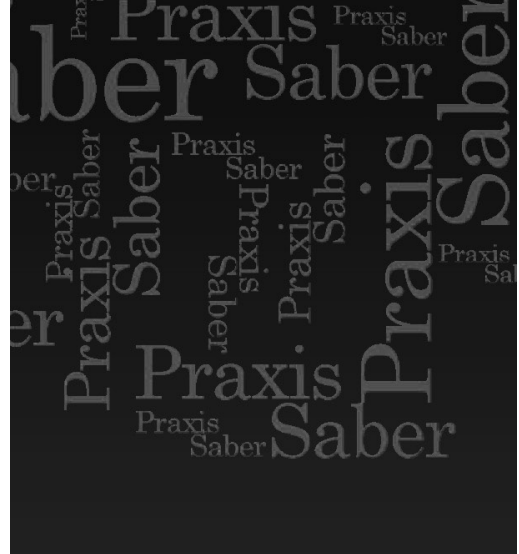

Ricardo Benjamín Toledo Castellanos

Magíster en Filosofía

Universidad del Rosario,

Bogotá

Maestro en Artes Universidad Jorge Tadeo Lozano, Bogotá

Docente Universidad Javeriana

Grupo de Investigación

Pedagogía, Tecnología y

Sociedad en las Artes Visuales

ricardobtoledo@gmail.com

Artículo de Investigación Científica y Tecnológica.

Recibido: 26 de febrero de 2012

Aceptado: 4 de octubre de 2012

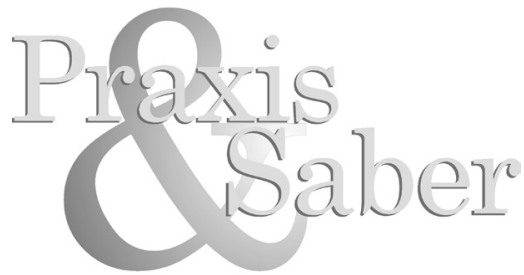

Revista de Investigación y Pedagogía Maestría en Educación. Uptc

\section{LAS INVESTIGACIONES ARTÍSTICAS, INVESTIGACIONES DE CONTEXTO}

Una rosa es una rosa es una rosa es una rosa Yo soy Rosa mis ojos son azules yo soy Rosa quién eres tú yo soy Rosa y cuando canto yo soy Rosa como toda cosa.

Gertrude Stein

\section{Resumen}

En este texto se plantean ciertos conceptos, presentes en obras del arte contemporáneo, que han abordado aspectos de la vida y que, pasados por la prueba sensible y expresiva, dan luces para fundar investigaciones sobre fenómenos singulares de la existencia. Para esto se argumenta que hay investigaciones propias del arte, investigaciones fundamentales que comprometen la certeza de los presupuestos en los que se cimienta el sistema de sentido de un contexto (época, cultura, nación, región). Estas investigaciones anticipan las investigaciones de los campos de enunciación racionaldiscursiva, ya que no pasan, aún, por ningún protocolo aceptado por comunidad alguna. La puesta en juego de la certeza se hace por un movimiento cognitivo llamado por Martin Heidegger 'desocultación', que consiste en la interrupción de la habitualidad de los entes que conforman el entorno familiar (confiable) para poner en percepción las estructuras fundamentales que permiten producir su sentido. La desocultación, propia del arte y las acciones creativas, constituye un acontecimiento que suspende la solidez del orden aceptado (social, ético, técnico, científico, filosófico) y desata condiciones para el cambio de los modos de vida mantenidos hasta entonces.

Palabras clave: investigación, contexto, desocultación, sentido, arte, praxis \& saber. 


\section{Artistic Research, Context Research}

\section{Abstract}

Some concepts in contemporary art works, dealing with some life aspects and passed through the sensitive and expressive test, are formulated in this paper and shed light on the foundation of researches about singular phenomenons of the existence. For this, it is argued that there are researches belonging to arts, fundamental researches that compromise the certainty of the assumptions where the sense system of a context has its bases (epoch, culture, nation, region). These researches come ahead of the researches of the rational-discursive enunciation fields, given that the last ones haven't passed any protocol accepted yet by any community. To bring into play the certainty is done by a cognitive movement named by Martin Heidegger unconcealment [Unverborgenheit], and it consist on the interruption of the habituality of the beings who form the (trustworthy) family setting to put into perspective the fundamental structures that allow to produce its sense. The unconcealment, typical in art and in creative actions, sets up an event that stops the solidity of the established (social, ethical, technical, scientific, philosophical) order, and unleashes conditions for changing the lifestyles hold until then.

Key words: research, context, unconcealment, sense, art, praxis \& knowledge.

\section{Les ReCHERCHES Artistiques, RECHERCHES DE CONTEXTE}

\section{Résumé}

Dans ce texte l'on décrit certain concepts, présents dans des œuvres d'art contemporaines, qui ont abordé des aspects de la vie et qui, passant par des épreuves sensibles et expressives, donnent des pistes pour fomenter les recherches sur des phénomènes singuliers de l'existence. Pour ce faire on argumente qu'il existe des investigations propres à l'art, recherches fondamentales qui engagent la certitude des présupposés dans lesquels se cimente le système de sens d'un contexte (époque, culture, nation, région). Ces recherches anticipent les investigations des champs d'énonciation 
rationnelle-discursive, puisqu'elles ne passent pas encore par un protocole qui soit accepté par aucune communauté. L'enjeu de la certitude se fait par un mouvement cognitif appelé par Martin Heidegger le 'dévoilement' (Alétheia), qui consiste dans l'interruption de la constance des êtres qui forment l'entourage familial (fiable) pour mettre en perception les structures fondamentales qui permettent de produire son sens. Le dévoilement propre de l'art et les actions créatives, constituent un événement qui suspend la solidité de l'ordre accepté (social, éthique, technique, scientifique, philosophique) et fait apparaitre des conditions pour le changement des modes de vie qui étaient maintenus jusqu'alors.

Mots clés: investigation, contexte, dévoilement, sens, art, praxis \& savoir.

\section{As Investigações Artísticas, Investigações de CONTEXTO}

\section{Resumo}

Neste texto se expõem alguns conceitos presentes em obras da arte contemporânea, que têm abordado aspectos da vida e que, feita a proba sensível e expressiva, dão luzes para fundar investigações sobre fenômenos singulares da existência. Para isso se argumenta que tem investigações próprias da arte, investigações fundamentais que comprometem a certeza dos pressupostos nos que se cimenta o sistema de sentido de um contexto (época, cultura, nação, região). Estas investigações antecipam as investigações dos campos de enunciação racional-discursiva, já que não passam, ainda por nenhum protocolo aceita por comunidade alguma. A posta em jogo da certeza se faz por um movimento cognitivo chamado por Martin Heidegger 'desocultação', que consiste na interrupção da habitualidade dos entes que conformam o entorno familiar (confiável) para pôr em percepção as estruturas fundamentais que permitem dar seu sentido. A desocultação, própria da arte e as ações criativas, constituem um acontecimento que suspende a solidez da ordem aceita (social, ética, técnica, científica, filosófica) e produz condições para a mudança dos modos de vida estabelecidos até agora.

Palavras chave: investigação, contexto, desocultação, sentido, arte, práxis \& saber. 


\section{Introducción}

Theodor Adorno hizo evidente en su 'Teoría estética' que la inclusión del arte entre los bienes de la sociedad de consumo se basa en la visión subjetivista del arte, a donde es llevado al ser concebido como fenómeno estético, visión dominante en la modernidad. La estética arranca al arte de su esencia creadora, cuya base más originaria es la vida del artista, con sus intereses y opiniones, para instaurar el sentido en la receptividad desinteresada de un espectador dotado de un gusto trascendental que lo juzgará. Y en esa condición, de pérdida de su origen y esencia, los ejes de sentido que le quedan son "que se convierta en una cosa más entre las cosas y el que sirva como vebículo de la psicología de quien la contempla” (Adorno, 1983, p. 31). Las obras de arte cosificadas ya no pueden producir más sentido que la sustitución del sujeto por el deseo estereotipado de sí mismo que cree percibir en ellas. La exigencia de desinterés en el juicio de gusto hace posible la dedicación al arte solamente a aquellos que no son interpelados por la vida que viven — con su situación histórica, sus afectos, sus opiniones y necesidades-, quienes no se encuentran acosados por los afanes de la supervivencia y la búsqueda del sustento, quienes no han tomado posición en el devenir de su época.

Giorgio Agamben retoma el planteamiento nietzscheano según el cual la figura mítica de Pigmalión representa el anuncio del interés vital que el artista ha puesto de nuevo en juego en el arte contemporáneo:

Pigmalión, el escultor que se exalta debido a su propia creación, hasta el punto de desear que no pertenezca más al arte sino a la vida, es el símbolo de esa rotación que va desde la idea de belleza desinteresada como denominador del arte, hasta la felicidad, es decir, a la idea de un ilimitado acrecentamiento y potenciación de los valores vitales, mientras que el eje de la reflexión sobre el arte se desplaza del espectador desinteresado al artista interesado (Agamben, 1998, p. 11).

Si bien el tiempo del arte está poblado por los afanes relativos a la realización de una obra, el tiempo de la vida está ocupado por la lucha contra la necesidad mediante el trabajo. Una obra de arte es algo que no se identifica ipso facto con los resultados normales de un proceso de trabajo, sin embargo, como lo expresó Guy Debord, en la obra "aquello que cambia nuestro modo de ver las calles es más importante que lo que cambia nuestro modo de ver la pintura" (Citado en Camnitzer, 2008, p. 318). Como realización del interés, el contenido vital de la obra se desvirtúa como producto y termina siendo algo que no se puede comprar o usar. Esa faceta del arte nos dice, sin embargo, algo fundamental sobre el interés vital del trabajo mismo. 
Algo nos dice el arte sobre el problema de la vida. El interés que el artista tiene en el mundo, en su condición de ciudadano y existente, ayuda a tejer la cercanía entre vida y arte, pasar de una al otro convirtiendo a la creación artística en un tipo de investigación fundamental cuyos hallazgos tienen directa aplicación en la vida. La filósofa Consuelo Pabón planteó una concepción de la relación arte/vida, según la cual "El artista se sumerge en el caos de su época, pero en vez de quedarse en la crítica social o en el espectáculo de la catástrofe, selecciona el acontecimiento que brilla dentro del caos y lo transforma en arte y vida” (Pabón, 2000, pp. 77-78). De modo análogo el artista y teórico Luis Camnitzer hace evidente que el nexo arte/ vida es atravesado por relaciones políticas:

[...] las disyuntivas asociadas con la discusión de arte/vida corren el peligro de centrarse en los instrumentos ignorando el papel de los polos del poder. Si centramos nuestra atención en los polos del poder, la relación arte/vida es un problema de una importancia menor a la que le atribuíamos, o por lo menos, un problema incompletamente formulado. [...] El problema quizás se debiera formular entonces más certeramente como Arte/Vida/Política (Camnitzer, 2003, p. 36).

Sobre esta relación, a propósito de la celebración de la octava Bienal de Arte de La Habana, titulada 'El arte con la vida', en medio de las dificultades derivadas de un boicot recrudecido del gobierno estadounidense y varios de la comunidad europea, denunciaba Hilda María Rodríguez:

Frente al canibalismo espiritual, la esquizofrenia política, la disfunción de las políticas culturales, es comprensible la relocalización de las prácticas desplazadas. Muchos han coincidido en que la producción de cultura significa producción de vida cotidiana. Pensemos entonces en la viabilidad de fórmulas de influencia del arte en los espacios de la vida, incluso a través de viejos patrones que puedan encontrar su sentido en el nivel social (Rodríguez, 2003, p. 24).

Por eso preguntamos ¿Qué es lo que el arte puede ayudar para alumbrar los aspectos de la vida no alcanzados por las formas institucionalizadas de la investigación hasta ahora dominantes? La respuesta no puede ya provenir de la estética sino del estudio del mundo, donde se entretejen relaciones de sentido entre arte, vida y política. Una investigación artística, si bien compromete bastantes elementos de las prácticas vitales, rebasa los límites de la anécdota biográfica y vivencial. Todo intento de estudio sobre las investigaciones artísticas va en busca de lo que se conserva en las obras. Resistiendo a la muerte del artista, de quienes lo conocieron y compartieron 
eventos biográficos con él, de los contemporáneos que compartieron experiencias generales de sentido en su cultura, su época y su sociedad, las obras de arte conservan formas de la sensibilidad que dieron contexto de sentido a la experiencia vital. Lo que queda en obras de arte de envergadura investigativa es la puesta en percepción del mundo, el mundo del artista, es decir el origen de un sistema de sentido desde el cual se configuró su coherencia expresiva, perceptual e icónica.

\section{El poder inaugural del arte}

La investigación es definida desde su origen, en la ciencia moderna, como un proceso mediante el cual se abren campos o regiones del saber para establecer objetos de estudio (dominios). La especialidad de toda ciencia mantiene, mediante el rigor, los límites de su campo y objeto de estudio, y los procesos mediante los cuales observarlo. Según Martin Heidegger, la delimitación de campos de estudio en la ciencia moderna tiene dos consecuencias:

1. La 'objetización' de lo existente. La noción de mundo es asumida como una totalidad que puede ser estudiada en partes o dominios, cada uno objeto de una ciencia. Y el conocimiento que lo interroga se puede parcelar entonces en campos, marcos de observación y de interés.

2. La institucionalización de los campos de investigación científica en empresas. El carácter de la ciencia moderna deriva del aislamiento de dominios y delimitación de campos, y cristaliza en empresas e instituciones. La especialización no es consecuencia sino razón del progreso de toda investigación, de ahí que la empresa es su proceso fundamental.

El hombre de ciencia, que interroga al mundo, se establece a sí mismo, en tanto sujeto del conocimiento, como modelo y medida de las magnitudes y las representaciones. El investigar interroga a lo existente para delimitarlo y ponerlo a disposición del representar (Heidegger, 2005b, p. 77). La representación es la figura esencial de la modernidad, la meta de la investigación, y lo existente, el mundo, es la imagen que el sujeto conforma en su pensamiento.

Carlo Federici, profesor emérito de la Universidad Nacional de Colombia, plantea en su artículo 'Algunos aportes relativos al problema de la investigación', la preponderancia que deben mantener en los procesos investigativos las relaciones dialécticas conducentes a informes sistemáticos 
(síntesis). El punto nodal de su propuesta es una relación articulada entre cuatro componentes como son sujeto-objeto y comunidad (social, académica) - mundo (totalidad de los hechos susceptibles de ser conocidos). La relación dialéctica enfrentaría términos como éstos para buscar espacios de síntesis que produzcan un sistema total, interconectado por dos fuerzas: intersubjetividad (sujeto-comunidad) e interdisciplinariedad (entre comunidades).

Son las instituciones las encargadas de facilitar el diálogo de saberes y de promover la interdisciplinariedad o "Trabajo de fuerzas convergentes" (Federici, 2002, p. 12). El saber se hace así sistemático, las investigaciones de cada campo del saber se complementan para ampliar su radio de acción, su alcance social y su aplicabilidad (por ejemplo, cuando en la construcción de un edificio cooperan los saberes de la geología acerca del suelo, de la ingeniería acerca de materiales y tensiones, la arquitectura acerca de las formas, los flujos y las relaciones funcionales, del urbanismo acerca del impacto social en el contexto de la ciudad, de la antropología acerca de las características diferenciales que aporta la cultura).

Muchas instituciones académicas, económicas y gubernamentales mantienen vigente el modelo de la ciencia moderna, y desde éste se asume que la investigación no es asunto del arte, ya que éste no aporta ninguna especificidad a la gran representación (científico-filosófica) del mundo. Según el modelo de la modernidad, el arte aprovecha marcos de observación y de interés de la experiencia común y a veces de los dominios de las ciencias o la filosofía, y no sustenta un nivel de especialización equiparable al de los otros dominios. La respuesta institucional al trabajo artístico es que su competencia es la creación, y sólo enfrenta labor investigativa en el sentido estricto cuando sale de su campo, puesto que no hay un objeto de estudio delimitado propio del arte, por lo tanto no es un campo del saber. Si hay algo interesante que descubrir en el arte, pertenece al campo de ciertos estudios sobre arte desde la historia, la historia del arte, la semiología, la iconografía, la psicología y otras, pero no del arte mismo. $\mathrm{O}$ se asume que su campo de investigación es eminentemente el de la búsqueda de nuevos medios representativos o expresivos. No se espera que en el arte se descubra nada importante (una nueva técnica o material para hacer obras, un estilo novedoso, una nueva interpretación musical o teatral).

Pero este modelo ha despertado sospechas en algunos filósofos y pensadores cuyo trabajo ha exigido respuestas vitales, topándose con problemas fundamentales de contexto. En su Tractatus lógico-philosophicus, dijo Ludwig 
Wittgenstein: "incluso si todas las posibles cuestiones cientificas pudieran responderse, los problemas de la vida quedarian todos por resolver. Desde luego que no queda entonces ninguna pregunta por hacer, y precisamente esa es la respuesta" (Wittgenstein, 1918, \6.52). Porque los problemas de la vida exceden y paralizan las tentativas de acercamientos conceptuales, las investigaciones que intentan racionalizar o representar su sentido se encuentran con un gran silencio. Los problemas de contexto requieren que el investigador reconozca la finitud (geográfica, étnica, histórica) de los principios fundamentales según los cuales los procedimientos, las observaciones, las condiciones de prueba y las enunciaciones conforman un sistema de sentido. Asimismo postuló Gregory Bateson que cualquier época [y contexto] es ciega a los fundamentos de lo que toma por cierto y evidente, es así que lo que puede entrar en cuestión son sólo las investigaciones, construcciones o formulaciones que se hacen siguiendo los presupuestos. Ya que no son enunciados de manera explícita, sino aprendidos como estructura subyacente a todo posible sentido, los presupuestos mismos no entran en cuestión salvo cuando un contexto se encuentra con su límite y descubre, en su finitud, su condición histórica.

Heidegger, en su artículo 'El origen de la obra de arte', planteó una sospecha análoga:

[...] a fin de demostrar y comprender lo correcto (la verdad) de un enunciado, no nos queda otro remedio que apelar a algo ya evidente. Este presupuesto es, en efecto, inexcusable. Mientras hablemos y opinemos así, seguiremos entendiendo la verdad únicamente como una corrección que ciertamente precisa de un presupuesto que nosotros mismos imponemos sólo Dios sabe cómo y por qué razón." (Heidegger, 2005a, p. 37).

En el camino de la pregunta por la esencia del arte Heidegger expone su relación fundamental con el contexto. Por este camino descubriremos, según el filósofo, "si el arte puede ser un origen y, por lo tanto, debe ser un salto previo, o si debe quedarse en un mero apéndice y, por lo tanto, sólo podemos arrastrarlo como una manifestación cultural tan corriente como las demás" (Heidegger, 2005a, p. 56). Si se queda en una manifestación cultural más, el arte se inscribe como testimonio cultural y funciona como huella o vestigio de lo típico de un sitio o época. Su valor tendría que ser establecido por los antropólogos o los etnógrafos y tasado por los historiadores o los mercaderes de rarezas. 
Pero si es un origen, la actividad artística permite superar la inmediatez encubridora del contexto de sentido de toda sociedad (no sólo de la moderna), desde la cual el orden dado es adoptado, pasivamente, como natural. Como 'salto previo', las obras de arte anticiparían las condiciones de nuevas formas de existencia, por ruptura o por ampliación de los umbrales de la normalidad. El arte es un instrumento privilegiado para comprender los procesos de conformación del sentido de nuestra existencia ${ }^{1}$ histórica.

\section{Las investigaciones artísticas problematizan el contexto, es decir, el sentido.}

Es evidente que el poder inaugural presente en toda actividad creativa, no es exclusivo del pensar artístico, pero éste "lleva a su punto extremo una capacidad de invención de coordenadas mutante, de engendramiento de cualidades de ser inauditas, nunca vistas, nunca pensadas” (Guattari, 1993, p. 83). En tanto no da por incuestionable ningún presupuesto, prescripción de uso, valor absoluto o verdad universal, el poder artístico consiste en inaugurar problemas, abriendo temas de investigaciones futuras. Desde su investigación, que tocó el límite entre la psicología y la filosofía, evidencia Félix Guattari que en la historia de Occidente se ha destacado tardíamente al arte como actividad específica que anima una referencia axiológica que le es particular, tratándose de la investigación intuitiva, sensible, anterior a su enunciación institucionalizable, la potencia de sentir, "ha pasado a ocupar una posición de privilegio en el seno de los Agenciamientos colectivos de enunciación de nuestra época” (Guattari, 1993, p. 78). Al ser tema del pensamiento los fundamentos del contexto, que agencian el sentido colectivo, pierden su carácter de presupuestos, se hacen susceptibles de impugnación, lo que quiere decir que desde el momento en que son enunciados explícitamente son elegibles y, si bien perdemos en certeza, ganamos la libertad de aceptarlos, rechazarlos o cambiarlos por otros. Pero hay una condición para que los principios fundamentales puedan ser enunciados: la posibilidad de percibirlos, reconocerlos, y esto requiere la intervención previa de la acción desocultadora, que interrumpa la habitualidad, y con ella la confianza, del contexto. De ahí que la entrada del arte sea necesariamente previa a la racionalización, teorización y enunciación de un problema de investigación.

\footnotetext{
El término alemán desarrollado por Heidegger es 'Da-sein', traducible al español como ser/estar-ahí. El término implica la relación del existente con el mundo-ala-mano, es decir con una estructura configurada históricamente.
} 


\section{El carácter dinámico de un contexto}

En el año 1990 la artista colombiana María Teresa Hincapié presentó por primera vez la obra 'Una cosa es una cosa', una acción en la que durante ocho horas fue desplegando el contenido de objetos de su casa en un pabellón de Corferias (complejo de bodegas destinadas a la realización de ferias comerciales, industriales, de gran alcance en la ciudad de Bogotá), el espacio de exhibición elegido para la realización del Salón Nacional de Artistas.
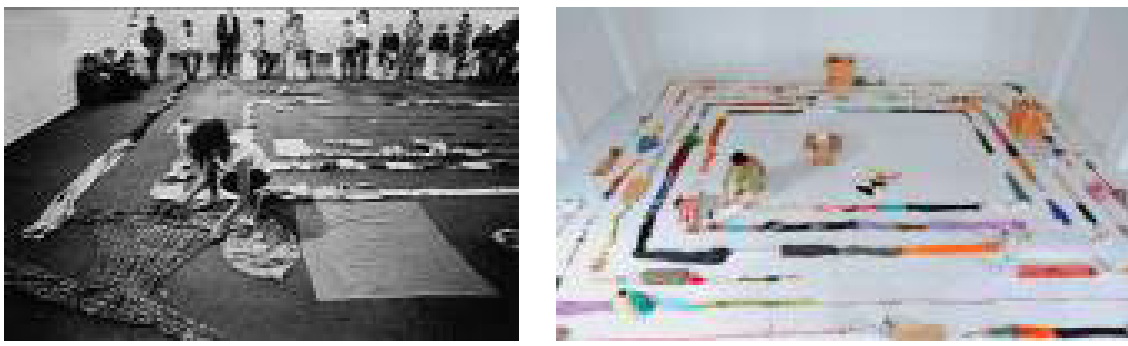

Imagen 01. María Teresa Hincapié (1954-2008), 'Una cosa es una cosa', 1990, 1998, 2005. Salón Nacional de Artistas, $4^{a}$ Bienal de La Habana, Galería Alcuadrado, Museo Iglesia Santa Clara.

En ese entonces yo era un artista recién graduado de una facultad de artes y contemplé la acción durante unos pocos minutos, ya que había demasiadas obras para visitar en el Salón de Artistas. Sin embargo me intrigaba saber cómo culminaría la acción, por eso revisé las notas y comentarios que los críticos publicaron, a raíz del reconocimiento hecho a la obra con el primer premio. Unas críticas reconocían gran originalidad en la obra, otras la veían simplemente extraña, pero todas en conjunto buscaban inscribirla en categorías abiertas por ciertos artistas conceptuales de los años sesenta y setenta (Joseph Beuys, Gina Pane, Chris Burden, Chantal Ackerman o Laura Mulvey), que servían como puntos de referencia para establecer su contenido. Todas las críticas resaltaron el hecho de que la artista no proviniera de una larga trayectoria en las artes plásticas sino del teatro. El resultado final fue una instalación que perduró en el espacio las semanas determinadas para el Salón de Artistas, y el registro en video de algunos momentos de su realización.

A mí me asaltaban inquietudes que no cabían y no eran abordadas por las voces oficiales del arte colombiano. La forma de la obra se me parecía a una escena de la película 'The Wall' del director Alan Parker, que había visto repetidas veces los años inmediatamente anteriores. En esa escena Pinky, el personaje protagonista, presa de un arrebato producto del extrañamiento y 
desaparición del sentido en el modo de vida que lo había absorbido (hasta sentirse como un ladrillo más en la pared que representaba al mundo), destrozaba por completo todo el contenido de objetos de la habitación del hotel donde se encontraba y luego, pasada la crisis, ordenaba con mucha concentración los pedazos y residuos inservibles, en una estructura lineal y concéntrica, nada funcional, en el piso.
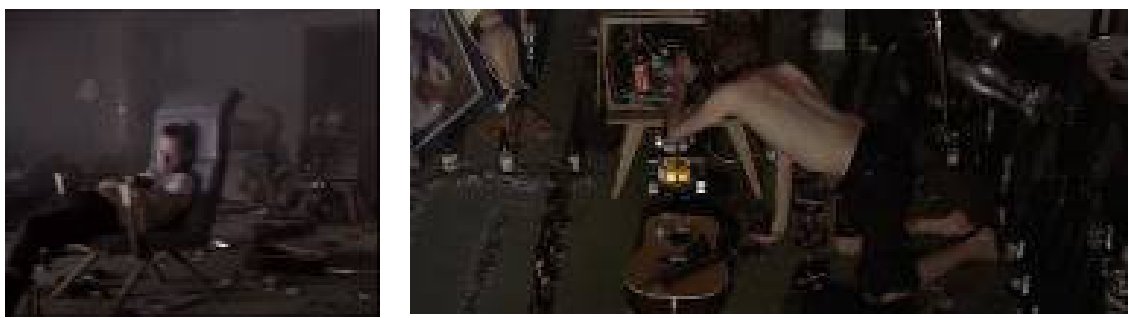

Imagen 02. Fotogramas de la película The Wall de Alan Parker.

Por otra parte me asaltaban preguntas que parecían ridículas o fuera de lugar en el medio intelectual, o por lo menos nadie formuló en voz alta, como ¿dónde va a vivir María Teresa mientras sus cosas están en el Salón?, ¿en qué va a tomar los alimentos?, ¿qué ropa se va a poner? En suma, la obra me hacía pensar en la vida, no podía sustraerme de los problemas de la vida ante la obra de arte, al contrario, la obra las suscitaba o las subrayaba.

Ante la obra, los conocidos y amigos que habían sido objeto de la hospitalidad y generosidad de la casa, habrán reconocido en los objetos los momentos de vida compartida con María Teresa. El pocillo en el que alguna vez les fue servido el café, el vaso en el que se les ofreció agua o vino, el cojín que calmó su cansancio, la estufa que calentó el alimento compartido, las ollas que lo contenían y los platos en que se les sirvió, iban siendo alineados en una espiral creciente trazada en el suelo. El público que pasaba podía reconocer también cosas comunes (no había cosas lujosas, por otro lado no eran objetos abstractos sino iguales o parecidos a los disponibles en el mercado), parecidos a las de otras casas. La diferencia estribó en que su no pertenencia a ese lugar las hizo visibles al pensamiento.

La misma artista respondió años después, a una pregunta sobre su intención en 'Una cosa es una cosa':

Yo necesito el pocillito para tomarme el agüita, el platico para la comidita. Muchas personas las pueden ver desde muchos ángulos, unas lo pueden apreciar, otras no. Hay un texto del taoísmo que dice: 
"No hay que hacerse cosa en las cosas". También la materia es muy mágica, está llena de energía, el vacío no más, de un pocillo, es un tratado filosófico sobre el vacío; pero entonces depende como uno vea las cosas, pueden ser cosas o pueden ser otras cosas (Hincapié, 2002).

La lección fue tomada muy en serio por la artista, las cosas nunca volvieron a la casa, la obra fue montada en otras dos ocasiones, pero el primer montaje marcó el acontecimiento que reveló una máxima para la vida: "no hay que hacerse cosa entre las cosas", y la manera de lograrlo es nunca dejar de pensar en medio de ellas, todo "depende de como uno vea las cosas". La casa de la artista nunca volvió a estar equipada como las casas típicas, unas cuantas fotos de obras suyas en las paredes, y lo apenas necesario para tomar el alimento, vestirse o descansar. Los últimos años de su vida tomó la opción clara y radical de tener máximo tres unidades de cada cosa, una para ella, otra para su hijo y otra para un invitado posible. Dijo María Teresa en una ocasión que "uno elige la existencia que le gusta y opta por formas de vida que le produzcan felicidad”, esto fue posible gracias a que su obra y su vida perdieron toda distancia. El asunto aquí es que cuando el arte y la vida se acercan tanto, cada uno emana pautas para sentir y actuar en el otro.

Por eso es que la obra de María Teresa nos pide buscar sus claves en la vida, y luego nos invita a regresar a ella con nuevas claves emanadas de la experiencia con la obra. En primer lugar las cosas fueron sacadas de la casa para establecerse en el espacio, exterior y público, del arte, estaban ordenadas pero ya no eran útiles. Las cosas de la casa de la artista fueron arrojadas a un espacio al que no pertenecían originalmente, para ser partes de otra estructura, la de una obra de arte que se exhibía. Las pautas de organización estaban dadas de modo visible por una espiral rectilínea, y las razones para la cercanía, lejanía o secuencia entre cosas guardaban algunas huellas de su significado y uso, según lo expresó la artista en el texto que acompañó las muestras de la obra:

[...] grupos comunes. donde se parecen. porque son blancos. porque son de tela. porque son vestidos. porque son de plástico. porque son largos. porque son cubiertos. porque es loza. porque son frascos. porque se necesitan el uno al otro como la crema y el cepillo. pero también la crema sola y el cepillo con otros cepillos o solo también. todas las flores aquí. los vestidos extendidos [...] (sic) (Hincapié, Texto complementario al montaje de la obra 'Una cosa es una cosa', 1990). 
Junto a las medidas estructurales, expresadas con términos de la cotidianidad como 'aquí, 'allá', 'en la esquina', 'a un lado', de los grupos y la secuencia emergían relaciones más vitales, existenciales: "[...] la bolsa sola. la tula sola. la caja sola y vacía. el espejo solo. los zapatos solos. las medias solas. las yerbas solas. yo sola. él solo. nosotros solos. un espacio solo. un rincón solo" (sic) (Hincapié, texto complementario al montaje de la obra 'Una cosa es una cosa', 1990).

Otras pautas oscilaban entre la funcionalidad suspendida y una cotidianidad problemática: "una línea sola. una sola media. un solo zapato. todas las cosas están solas. todos estamos solos. un montón de arroz. un montón de azúcar. un montón de sal. un montón de harina. un montón de café. un montón de cosas [...] " (sic) (Hincapié, texto complementario al montaje de la obra 'Una cosa es una cosa', 1990).

La constante ida y vuelta entre vida y obra, restaba familiaridad al grupo de cosas, al tiempo que sembraba dudas sobre el carácter artístico de la acción. La desestructuración de las cosas de la casa las hizo extrañas de su ámbito cotidiano donde son útiles, y en esa extrañeza se hacían visibles. A la vez, estar viendo como obra de arte los objetos de una persona, objetos usados, pertenecientes a una vida, hacía extraño el ámbito artístico, que también quedaba a la vista. Había un gran desfase entre lugar y cosas, y esto desestabilizaba la normalidad de ambos, sacándolos de su familiaridad, haciéndolos tema del pensamiento. Esta desconfianza fue llevada por algunos de los asistentes, en mayor o menor grado, al volver a sus casas.

Obra y vida entraron en una zona de frontera que alteró las dos. La artista trasladó operaciones y decisiones de una a la otra. Un año antes, en obras como Vitrina y Punto de fuga, había realizado labores como barrer, trapear, planchar, acompañadas por diatribas y acciones problemáticas como besar una vitrina dejando la huella de sus labios en lápiz labial, pintar con jabón su cuerpo o aminorar la marcha de sus movimientos. La duración de las obras establecía significaciones que cuestionan el papel social de los trabajadores y las mujeres (Vitrina duró las ocho horas de la jornada laboral, en Punto de fuga trabajaba durante doce horas cada uno de los tres días que duró). La maduración posterior de su obra la llevó a la realización de acciones, con fuertes contenidos rituales, destinadas al cuidado de la tierra y la vida, como 'Divina proporción', 'Hacia lo sagrado', 'Tú eres santo', 'Peregrinación hacia los Huicholes'. 
La constancia y solidez de su obra le valió el reconocimiento nacional e internacional en diversos eventos artísticos, y un respaldo institucional, que no pasó de retórico, a proyectos de mayor escala como establecer cerca de la Sierra Nevada de Santa Marta un lugar para el aprendizaje del cuidado de la vida y la preservación del equilibrio entre la vida moderna y los flujos naturales, mediado por la sabiduría antigua de pueblos como los Arhuacos. Su obra final ya no tenía como destino las exhibiciones de arte sino el mejoramiento de las relaciones de la vida humana con la naturaleza.

El arte y la vida estaban tan cerca que se parecían demasiado, María Teresa había inventado un arte de vivir que quiso enseñar hasta el momento de su prematura muerte. En esta zona de frontera no es posible utilizar conceptos típicos de la crítica de arte o de la estética, hay un lenguaje propio del arte, que parte de la singularidad de la obra para que pueda desarrollarse en ella lo que podría hacer al arte propiamente universal, preguntas que van renovando el mundo, ¿cómo encontrarle un sentido a la existencia?, ¿qué es el sentido para tener que acontecer en algo creado?

En la primera mitad del siglo XX Martin Heidegger percibió por la misma ruta de la determinación espacial de la existencia, la respeccionalidad (las cosas poseen un valor respecto de nuestros fines y nuestra vida) y circunspección de las cosas en las diferentes zonas de la existencia, el camino hacia la cuestión fundamental de la pregunta por el ser. El componente inicial de la investigación heideggeriana es la estructura espacial de la existencia del hombre, en la cual su vida tiene sentido. El hombre es un ser que hace preguntas, que pregunta por el ser, esa es su 'manera de ser'. La pregunta por el ser del hombre, tal como lo propone Heidegger, requiere una formulación óntico-ontológica: el hombre, un ente que pregunta por el ser (ontológico), participa al mismo tiempo del atributo 'ser' (óntico), y también es el ente que existe preguntándose por lo que hace del ser el modo de su existencia (óntico-ontológico). Según Heidegger la existencia es la estructura originaria que permite desplegar el habitar, en la forma de ser/estar-ahí (da-sein) en-elmundo. Solo nos es posible preguntar por el sentido de la existencia desde la experiencia misma de existir, originaria y a la vez oculta al pensamiento.

En nuestra posición, óntico-ontológica, el preguntar mismo es un acto de la existencia, la existencia se constituye en pregunta: ¿Qué es la vida?, ¿qué propósito tiene la existencia?, ¿para qué esforzarse? Estas preguntas se afincan en una pregunta que parece imposible siquiera de formular: la pregunta por el ser. La situación es angustiosa, problematizar la existencia nos hace perder la inicial familiaridad con el mundo. 
La angustia de la separación hace del hombre un ser 'arrojado en el mundo' que pregunta ¿quién soy?, ¿qué soy?, pero no tiene los elementos para siquiera formular la pregunta del ser (para preguntar ¿qué es el ser? tendríamos que poseer un saber previo sobre el ser que el ser es). La angustia puede conducirnos a la parálisis. Se fuga entonces el sentido que aliente el esfuerzo o la persistencia, y da lo mismo hacer las cosas que no hacerlas, no hay razones claras para despertar, madrugar o levantarse del lecho, para hacer planes, la vida no tiene sentido. ¿Qué es la vida?, ¿qué propósito tiene la existencia?, ¿para qué esforzarse?

Salir de la caída requiere que el sentido retorne, no porque las preguntas se resuelvan sino porque dejan de paralizarnos. Ese ser arrojado debe hallar de nuevo la familiaridad que dote de sentido su entorno y las operaciones ejercidas en éste. El Da-sein, expuesto a la infinitud y la falta de sentido, ha de concentrarse en las estructuras que su actividad alcanza a afectar, ocupándose ${ }^{2}$ de su mundo circundante. La operación clave para el retorno del sentido es el cuidado que al ocupar al existente, dota de sentido, provee metas, a su vida.

El término ‘mundo’ es usado por Heidegger en su sentido más común, que hace referencia a la estructura espacial asociada a nuestras prácticas (el espacio del arte, el espacio de la vida cotidiana, con sus acciones y sus desplazamientos), y no al espacio físico-técnico (Galileo, Newton, según el cual el mundo comprende el dominio último y absoluto que contiene la totalidad de las cosas). Se trata del mundo a la mano, el que se recorre habitualmente, que nos ocupa, que cuidamos, el que solemos llamar cotidianidad. El mundo, en ese sentido, está constituido por el acontecer ordinario, es decir el conjunto de actividades que nos ocupan mientras resolvemos algún asunto de nuestra vida, y también por el conjunto de cosas involucradas en la estructura espacial que nos es familiar y en cuyo interior esta vida se desenvuelve.

La cotidianidad conforma el sentido del orden que nos orienta en el mundo, cada vez que queremos saber dónde está —o dónde debería estar — cada

2 He preferido usar las expresiones 'ocuparse' o 'cuidar', más cerca del sentido pragmático desarrollado en este texto, de la traducción de Jorge Eduardo Rivera (Editorial Trotta): "este término [Besorgen, ocuparse de algo] no se ha escogido porque el Dasein sea ante todo y en gran medida económico y 'práctico', sino porque el ser mismo del Dasein debe mostrarse como Sorge, 'cuidado' " (p. 83); en lugar de 'curar(se)' de la traducción de José Gaos (Fondo de cultura económica): "La expresión [curarse de] no se ha elegido porque el 'ser abi' sea inmediatamente y en gran medida económico y práctico, sino porque el ser mismo del 'ser ahi' es, como se verá, 'cura' " (pp. 69-70). 
cosa. Las ocupaciones de nuestro mundo habitual requieren la ayuda de útiles, cosas que sirven para algo, alguna 'función' para la cual están ahí, a la mano, en una zona destinada para ellos, donde se espera encontrarlos cuando se necesitan. La condición de lo familiar es que no sea tema del pensamiento, es decir que se mantenga insignificante, para Heidegger la zona está a la mano más originariamente que las cosas que la ocupan, en esto reside el carácter de lo familiar, que no llama la atención (Heidegger, 2006). Lo familiar de la zona sólo es visible cuando, por deficiencias en el uso, nos vemos obligados a interrumpir las ocupaciones, "Cuando no se encuentra algo en su lugar propio, la zona se vuelve, con frecuencia por primera vez, explícitamente accesible en cuanto tal” (Heidegger, 2006, p. 129).

Puede pasar que los útiles pierdan su insignificancia, que pensemos y preguntemos sobre ellos: ¿quién cerró la puerta?, ¿por qué se regó el agua?, ¿dónde está el martillo?, ¿por qué no funciona el teléfono?, ¿por qué la silla es tan incómoda? $\mathrm{Y}$ entonces ya no son confiables. Cuando los útiles no

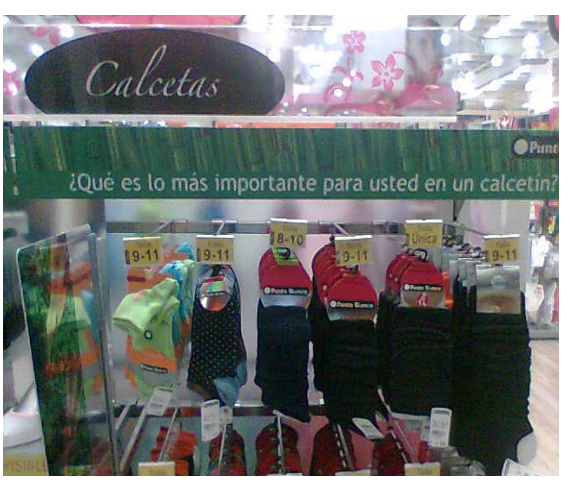
están averiados, están bien fabricados y se encuentran en su sitio y a la mano (en su zona), nos ocupamos sin preguntar.

Imagen 03. Estand publicitario de punto de venta en un supermercado de Bogotá, 2009.

¿Qué es lo más importante para usted en un calcetín? Al parecer una pregunta como ésta tiene un carácter tan obvio que no merecería ningún tipo de elaboración ni puesta en problema. Ya que la pregunta nos es presentada en una zona de mercado, frente a un mostrador de calcetines, es mas bien una incitación a la acción llana y directa de la compra: interroga sobre la idoneidad de los calcetines que tenemos puestos, y la posibilidad de cambiarlos por los que se están exhibiendo.

Lo más importante en un calcetín es que esté disponible para el uso y se adecúe completamente a éste, que esté bien hecho, que no se rompa, que sea del color adecuado, que venga acompañado de otro igual. Como lo dijo Heidegger "las respuestas a la pregunta sobre lo que es la cosa, son de algún modo tan corrientes que ya no se siente su problematicidad” (2005a, 
p. 44). La pregunta es insólita, interrumpe la confianza con que todos los días, sin pensarlo mucho, nos calzamos los pies y nos dedicamos a resolver los problemas que el sustento nos presenta. Un mal calcetín rompería nuestros hábitos, por incómodo, por no-disponible, por averiado. Una cosa que nos haga pensar en ella no es de confianza. Lo más importante de un buen calcetín es que no se tenga que pensar en él, que sea de confianza, que se mantenga 'insignificante', escapando del pensar, como todas las cosas que nos son familiares. La pregunta del supermercado resta confianza a los calcetines que usamos y nos ofrece en venta unos nuevos y más confiables (o de lo contrario no tendría sentido la pregunta).

La determinación de cosa tiene su origen en una interpretación del serutensilio del utensilio, en el proceso de utilización encontramos su carácter, su familiaridad, cuando ni siquiera las miramos ni las sentimos. Eso es lo importante de un buen par de botas de trabajo, un "par de botas de campesino", por ejemplo, como las pintadas por Vincent Van Gogh . ¿Qué puede verse allí en el cuadro de Van Gogh? — pregunta Heidegger — todo el mundo sabe en qué consiste un zapato, un tipo de utensilio que sirve para calzar los pies, en el caso de las botas, con el fin de trabajar en el campo, donde son precisamente lo que son, "Lo son más cuanto menos piensa la labradora en sus botas durante el trabajo, cuando ni siquiera las mira ni las siente” (Heidegger, 2005b, p. 23).

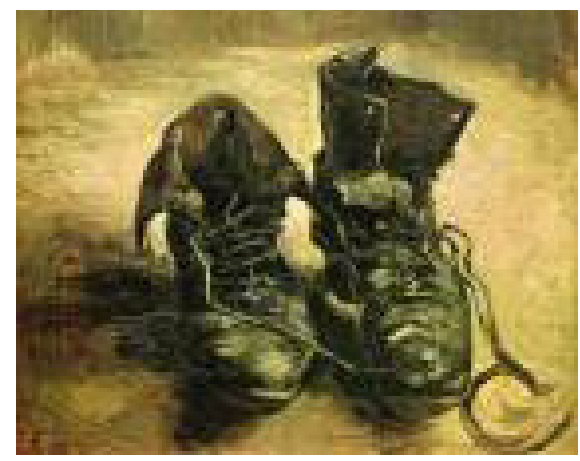

Imagen 04. Vincent Van Gogh (18531890), Un par de zapatos, 1886. Museo

Van Gogh, Holanda.

Pero las botas de Van Gogh son menos de lo que son cuanto más nos hacen pensar, no están ahí, listas para el uso, están pintadas en una obra de arte. Son, probablemente, las botas de una campesina francesa del siglo XIX (hace tiempo muerta), en una obra de un artista muy famoso (también hace tiempo muerto) colgada en la pared de un museo. No hay alternativa, sólo podemos mirar las botas y pensar en ellas, no son botas de confianza. 
Y sin embargo la pintura de Van Gogh lo es en la medida en que nos hace pensar. Lo que ocurre con las botas del cuadro de Van Gogh es que desde el comienzo no se esperaba que fueran confiables, insignificantes, todo lo contrario. Las botas fueron puestas en el cuadro para ser tema para el pensamiento:

En la oscura boca del gastado interior del zapato está grabada la fatiga de los pasos de la faena. En la ruda y robusta pesadez de las botas ha quedado apresada la obstinación del lento avanzar a lo largo de los extendidos y monótonos surcos del campo mientras sopla un viento helado. En el cuero está estampada la humedad y el barro del suelo. Bajo las suelas se despliega toda la soledad del camino del campo cuando cae la tarde. En el zapato tiembla la callada llamada de la tierra, su silencioso regalo del trigo maduro, su enigmática renuncia de sí misma en el yermo barbecho del campo invernal. A través de este utensilio pasa todo el callado temor por tener seguro el pan, toda la silenciosa alegría por haber vuelto a vencer la miseria, toda la angustia ante el nacimiento próximo y el escalofrío ante la amenaza de la muerte. Este utensilio pertenece a la tierra y su refugio es el mundo de la labradora (Heidegger, 2005a, pp. 23-24).

El existente con sus preocupaciones y esperanzas, el mundo que recorre a diario y la tierra que lo alberga, lo llama y renuncia a sí misma en el regalo del trigo se establecen los bordes cerrados de la obra de arte. Heidegger instaló la pregunta por el origen de la obra de arte en su carácter inicial de cosa. Hubo de traspasar la artisticidad de la pintura para que apareciera en ella el asunto mismo de las botas representadas, su cosidad. La interrupción de la familiaridad, la confianza tanto en la cosa como en la cosa-obra es lo que permitió la aparición del mundo. Cuando la obra ha 'hablado', la distancia entre vida y arte se reduce, y se abre para nosotros el 'mundo' de la campesina, la mundanidad de las botas, el silencio generoso de la tierra.

En la apertura de un mundo surgen otro tipo de preguntas que también comienzan por los útiles, como: ¿por qué hay quien no tiene zapatos?, ¿por qué el agua tiene precio?, ¿por qué hay disponibles tantas armas y tan pocos alimentos en el mundo?, ¿en qué consiste el ser martillo de un martillo? Estas son preguntas que apuntan al origen del sistema dentro del cual, por ejemplo, labrar la parcela, hacer una silla, sentarse, golpear una puntilla con un martillo, reunir ladrillos para hacer una casa, pedir agua en un vaso, tienen sentido.

Para conocer el ser obra (artisticidad) del cuadro de Van Gogh hubo que buscar su carácter más originario, su cosidad, en la cosidad de las botas. El 
ser cosa (cosidad) de las botas estaba ya interrumpido en la obra de arte, por eso salió de lo oculto, a nuestra percepción, el carácter de 'ser de confianza', su familiaridad, y con ella la zona del mundo recorrida cotidianamente por la campesina. La obra de María Teresa Hincapié fue por el mismo camino en dirección opuesta; la cosidad, interrumpida por la artisticidad, hace patente la mundanidad. Esta interrupción requiere de la desestructuración de la zona, que suspende el sentido habitual. El espacio de la obra desoculta su propia espacialidad, su costumbre, su organización de lo familiar, su manera de disponerlo a la mano.

Siempre parto del espacio, porque el espacio está conformado precisamente de esa multiplicidad de espacios. Este espacio de tu oficina, es un espacio, pero afuera también hay un espacio del espacio, y así sucesivamente. Entonces, el espacio te habla del tiempo, cada espacio tiene tiempo, un ritmo, una velocidad, o tiene una lentitud, tiene quietud, tiene repetición, y cuando yo voy a hacer un performance, precisamente me voy al espacio para pedirle permiso, para que me permita habitarlo (Hincapié, 2002).

María Teresa denunciaba cómo, en el aparecer de las cosas, en cada una de las zonas (como una oficina), el espacio le hablaba, salía de lo oculto, se abría. Sobre esto, Heidegger, a quien la obra de Van Gogh le habló del mundo de una campesina, señala que el ser-obra de la obra (su artisticidad) existe solamente en la apertura. En ella se instala, al tiempo que se produce, el acontecimiento de la desocultación del problema de la existencia. Al hacer visible la habitualidad que hace que los entes sean 'de confianza', se hacen visibles las estructuras fundamentales que constituyen el sentido de ese orden, su mundanidad. Sólo después de su puesta en problema es posible captar temáticamente un mundo.

Si yo no soy yo, no percibo o no intuyo; a través de la percepción descubro lo que el espacio me está diciendo. En este momento ya todo me habla. Yo aprendía a hablar con los objetos, cuando estaba trabajando en el performance: "UNA COSA ES UNA COSA", que me demoraba doce horas seguidas, con esas mismas cositas, se volvieron como seres, empezamos una relación trascendental (Hincapié, 2002).

Porque la artista abrió sitio en la obra para las cosas, con cada cosa abría la percepción de un sitio creado antes que ella (dejar que hablen). Heidegger descubrió el aspecto más originario de la cosidad de una jarra en el escanciar, la oferta amable y generosa del vino o el agua, que existe antes que cualquier 
jarra particular. El escanciar de la jarra, la esperanza de vencer la miseria en los zapatos, el alojar, descansar, llegar, tener un hogar en las cosas de la casa, son aspectos de una apertura que es liberada a la percepción en la vida y el arte: una espacialidad "que en la apertura de un paraje que lo encierra, condiciona una liberación en su encuentro, permitiendo la presencia de las cosas en ese instante, y el habitar del hombre en medio de las cosas" (Heidegger, 2009, p. 29).

La condición estable del mundo, más estable en sus producciones que en sus actividades, y más permanente que la vida de un ser humano, y sin embargo cambiante por la obra conjunta de la vida humana, abre la pregunta ¿Cuál es entonces el ámbito espacial de una obra de arte? Lo que sugiere el concepto de mundo, tal como lo presenta Heidegger y lo mantiene Hannah Arendt, es que si bien hay ciertos ámbitos de la vida de los que no se pueden desprender el filósofo, el artista y el existente común, desde los cuales ejercen su actividad, y no son exclusivos del artista, hay ámbitos especialmente propicios para mostrar en la obra de arte lo que sucede en la experiencia existenciaria.

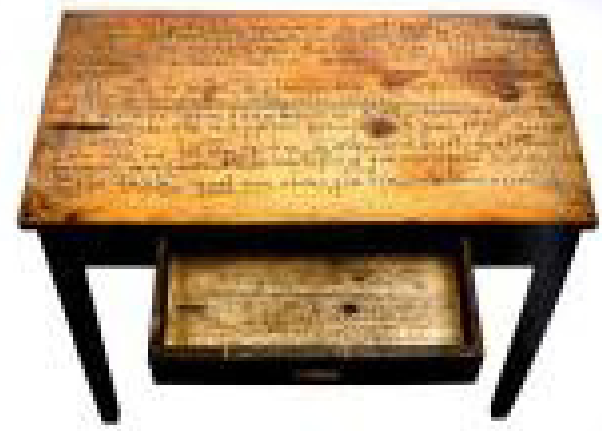

Imagen 05. Víctor Grippo (1936-2002), Tabla, 1978.

El logro de la obra no reside en la elección, ni siquiera en la construcción de ese ámbito, sino en la apertura de ámbitos posibles en el mundo ya existente, donde se logre abrir el sentido del actuar de la vida humana, y no sólo la de un hombre. La obra 'Tabla' del artista argentino Víctor Grippo es una mesa común y muy usada, sobre cuya superficie escribió a mano alzada el siguiente texto:

Sobre esta tabla, hermana de infinitas otras construidas por el hombre, lugar de reunión, de reflexión, de trabajo, se partió el pan cuando lo hubo; los niños hicieron sus deberes, se lloró, se leyeron libros, se compartieron alegrías.

Fue mesa de sastre, de planchadora, de carpintero... Aquí se rompieron y arreglaron relojes. 
Se derramó agua y también vino. No faltaron manchas de tinta que se limpiaron prolijamente para poder amasar la harina.

Esta mesa fue tal vez, testigo de algunos dibujos, de algunos poemas, de algún intento metafísico que acompañó a la realidad.

Esta tabla, igual que otras, y la transubstanciación de... (sic)

Gran parte de la potencia expresiva de la obra reside en lo común y gastado de la mesa, y la poca pretensión formal y técnica del artista, otra parte reside en el carácter cotidiano de la escritura y las pocas pretensiones formales del texto. Mucha de la fuerza de la obra reside fuera de sí, adonde la conduce el artista. La obra ya no se ocupa de sus técnicas, de sus procedimientos, de sus materiales, sino de los de la vida. La obra rompe el ámbito del predominio del objeto artístico, al renunciar a una visión estética o formalista, el arte se corre a un lado para dejar que aparezca la vida.

Derivada de esta obra, Grippo realizó un montaje llamado 'Mesas de trabajo y reflexión’ para la quinta Bienal de La Habana, en 1994, que consistió en la instalación de un grupo de mesas viejas y usadas, con textos escritos y algunos objetos y materiales sobre ellas, en un espacio de la Quinta del Morro. Según los testigos, Grippo "llegó a La Habana con las manos vacías", ya que había pedido que las mesas fueran conseguidas alli, "mesas rectangulares de madera, comunes que conseguiremos alli. Mesas ya usadas (cuanto más usadas mejor, las más simples y menos decorativas que podamos obtener)". Ese era un año difícil para la economía cubana, y aún más para la bienal, cuya celebración se había tenido que posponer un año por dificultades económicas. Unas mesas fueron encontradas por el mismo Grippo en una escuela vecina del centro Wilfredo Lam (sede de la bienal), eran mesas averiadas y algunos pupitres, también averiados; otras al parecer procedían de un restaurante que las había desechado. Dice Lilian Llanes presidenta en ese entonces del centro Wilfredo Lam: "con todas esas mesas gastadas por su uso, un poco de tierra, un pedazo de tela, un cuchillo, un espejo, algunos granos, una gran poesía y mucho de bumanidad, comenzó Víctor Grippo su obra de la quinta Bienal de La Habana” (Llanes, 2004, p. 44).

Las mesas tenían escritas frases de diversos autores, entre ellos Grippo. Una de las mesas repetía el texto de 'Tabla' de 1978, algunos otros textos eran:

-'un domador' No encuentro a quién contarle que en la rodada de esta tarde he muerto. Jorge Calvetti (Poeta). 
-"De cómo templar un trozo de acero. -Cubrir el acero con sal y raspaduras de pezuña de caballo. - Calentar al rojo cereza. -Sumergir rápidamente en agua fría".

-"La sociedad niega la especie y reniega del hombre si no se propone hacer de cada individuo un artista".

-"Allí donde la tierra tembló una vez, lo más probable es que vuelva a temblar. S. Gershanik (sismólogo)”

-"Resistencia de materiales. 'Un material experimenta, en el sitio de contacto con otro, un estado de tensión triaxial. Las tensiones principales están en el centro del área de contacto' (Ingeniero Guzmán)".
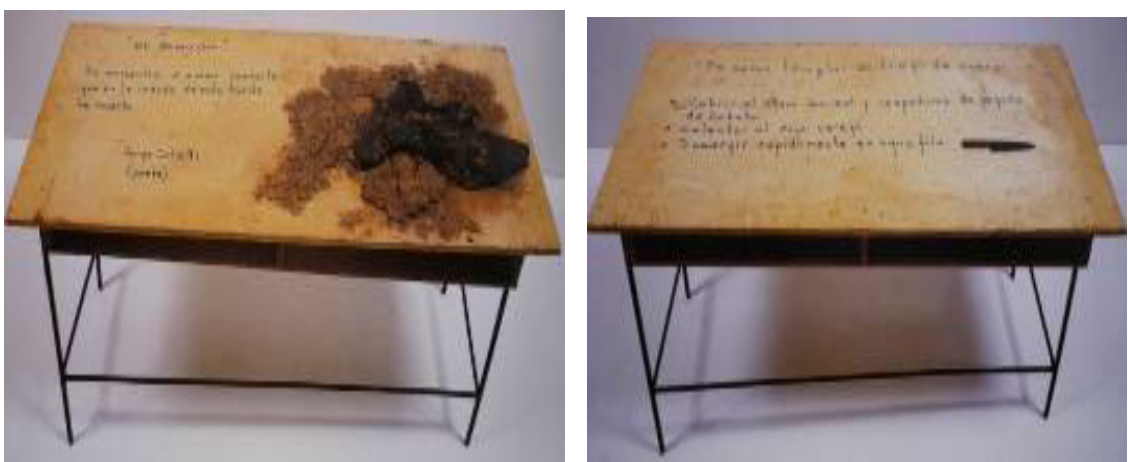

Imagen 06, 07. Víctor Grippo (1936-2002). Mesas de trabajo y reflexión. $5^{\text {a Bienal }}$ de La Habana 1994, Quinta del Morro.

Consciente y solidario de las dificultades de la bienal, Grippo construyó finalmente un ambiente acogedor alrededor de las mesas, que hacía sentido alrededor de las preocupaciones de muchos habitantes de Cuba, Latinoamérica y el Tercer Mundo. Los textos y objetos sobre las mesas agrupaban en el mismo espacio diferentes niveles del conocimiento que emana del trabajo. El trabajo del poeta, el sismólogo, el herrero, el ingeniero, el pensador, juntos en la obra del artista, eran el trabajo del hombre, el conocimiento y trabajo colectivo cuya obra es el mundo.

El mundo es "La condición humana" en dos sentidos: condición creada en la naturaleza por la actividad del hombre, y la condición que posibilita la acción del hombre en medio de un ámbito abierto en la naturaleza. Para la filósofa Hannah Arendt "Cosas y hombres forman el medio ambiente de cada una de las actividades humanas, que serían inútiles sin esa situación; sin embargo 
ese medio ambiente, el mundo en que hemos nacido, no existiría sin la actividad humana que lo produjo" (Arendt, 1958, p. 37). El mundo en que hemos nacido ya estaba formado. El mundo es la expresión del conjunto de las cosas, y de los hombres, en medio de ellas, produciendo y conservando el mejor modo de vida posible. El trabajo construye el mundo, en la medida en que crea un ámbito de sentido para que en su interior se desarrolle la vida humana, por acción del trabajo conjunto de los hombres que existieron antes que nosotros. La obra hizo patente que el mundo, condición que el hombre ha dado a su existencia, ha sido construido por la reflexión y el trabajo del hombre, y por tanto podría ser cambiado por la acción de éstos.

Dada la carga histórica que antecede al mundo, la existencia emerge con carácter fáctico para hacer comparecer lo descubierto en él. Luego de nacer a la vida nos espera nacer al mundo, aprender todo lo necesario para actuar en él, para vivir como hombres dentro de él. Por eso Arendt subraya el hecho de que el mundo mantiene su estabilidad mediante el trabajo que produce las cosas y, con ellas, el sentido de la realidad: "La realidad y confiabilidad del mundo bumano descansan principalmente en el hecho de que estamos rodeados de cosas más permanentes que la actividad que las produce, y potencialmente incluso más permanentes que las vidas de sus autores" (Arendt, 1993, p. 109). El mundo puede constituirse así en un ámbito cerrado en el cual nuestra existencia tiene un lugar prefijado desde antes de nacer, como la jarra, el zapato o la mesa. Pero no es eso de lo que habla la obra de Grippo, en el ámbito de la obra el mundo experimenta una apertura similar a la expresada en la máxima de María Teresa Hincapié: "no hay que hacerse cosa entre las cosas".

Grippo ya había planteado acercamientos entre arte y trabajo en una obra anterior como 'Construcción de un horno popular para hacer pan', obra realizada en conjunto con el artista Jorge Gamarra y el trabajador campesino A. Rossi para un evento al aire libre ${ }^{3}$. El artista planteaba la importancia de la recuperación del trabajo colectivo y hacía alusión al desplazamiento del campo a las ciudades de su país Argentina.

3 Formó parte de la muestra 'Arte e Ideología -CAYC al aire libre- Arte de sistemas II', en la plaza Roberto Arlt de Buenos Aires en 1972. 

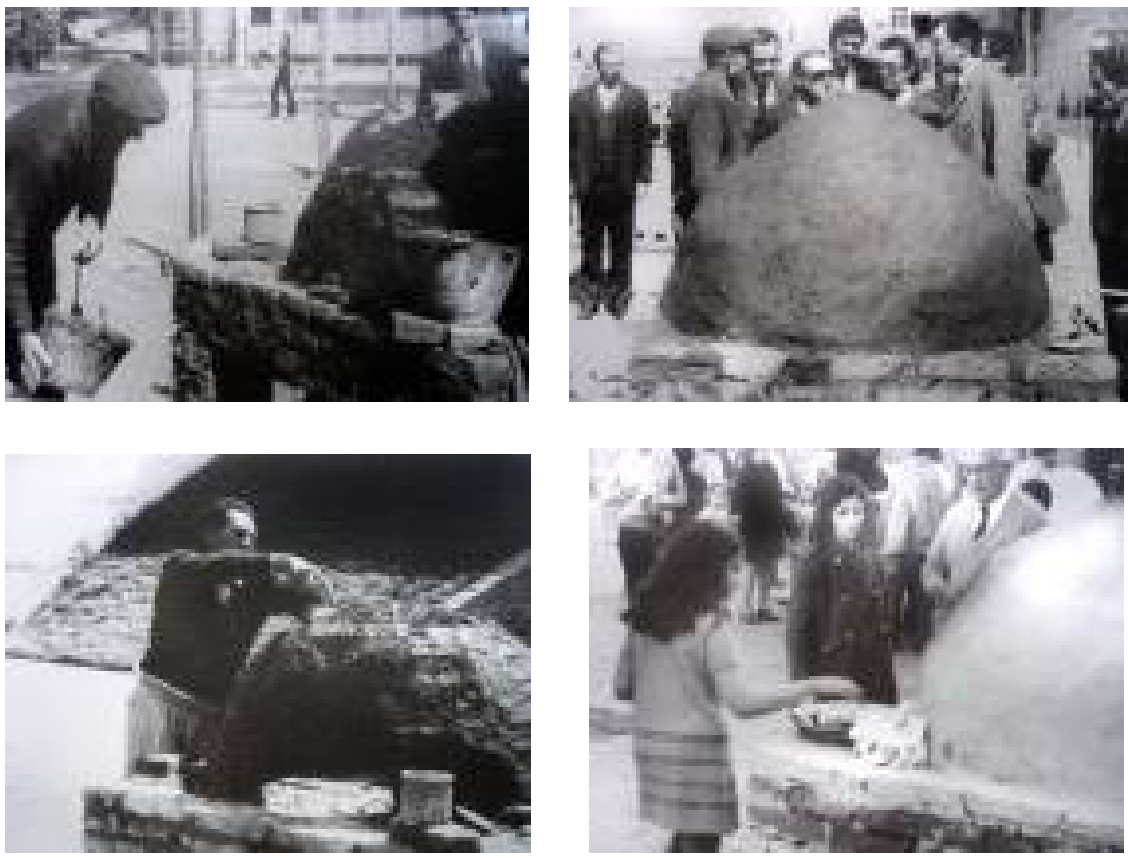

Imagen 08, 09 10, 11. Víctor Grippo (1936-2002). Construcción de un horno popular para hacer pan, 1972, con Jorge Gamarra y A. Rossi. 'Arte e Ideología CAYC al aire libre-Arte de sistemas II', plaza Roberto Arlt, Buenos Aires.

Los pasos de desarrollo de la obra planteados por Grippo fueron "a) construcción del horno, b) fabricación del pan y c) partición del pan”; más el intercambio de información con todos aquellos que pasaban, en el cual se buscaba un resultado pedagógico. Según el artista y escritor uruguayo Luis Camnitzer la obra de Grippo ponía en acción estrategias unificadoras de agitación y construcción. Tres días después de la inauguración, la exposición fue clausurada por la policía, al determinar que varias de las obras contenían sentidos políticos indeseables para el Estado. Durante las décadas de los sesentas y setentas una gran cantidad de obras de arte fueron censuradas o clausuradas porque, a los ojos de los agentes del Estado, promovían ideas de carácter subversivo. Declara Camnitzer que "en el contexto latinoamericano, no importaba qué posición uno tomaba, siempre significaba coquetear con la subversión” (Camnitzer, 2008, p. 22).

Realizar un horno en lugar de una obra de arte coqueteaba con la subversión porque hacía ver que el artista es ante todo un existente que construye e inventa espacios del mundo y no solamente ocupa los ya disponibles (en la 
vida y en el arte). Con el horno y el pan se abre el mundo en el sentido en que reclama la ampliación y mejora de las condiciones para pensar y vivir la vida. Contemplada como obra de arte, en la calle y no en la panadería, la cosa que es un horno permite aparecer al existente que necesita el pan, al panadero que trabaja y al albañil que hace hornos, como miembros de la misma comunidad de trabajo que, juntos, luchan por liberar espacios para la vida tal como se está viviendo en el momento, en su condición histórica. Por eso dijo Heidegger que cuando "acontece el arte, es decir, cuando bay un inicio, la historia experimenta un impulso, de tal modo que empieza por vez primera o vuelve a comenzar” (Heidegger, 2005a, p. 36).

La vida que se desarrolla en el mundo recibe una invitación de éste a mejorarlo, siempre y cuando los presupuestos que lo sostienen no queden ocultos al existente. De ahí la importancia que tiene el acontecimiento de la desocultación. "La verdad que se abre en la obra no puede demostrarse ni derivarse a partir de lo que se admitía hasta abora. La obra rebate la exclusividad de la realidad efectiva de lo admitido hasta ahora" (Heidegger, 2005a, p. 36). Porque el sentido de la existencia es más dinámico que el de las cosas, y puesto que el mundo es obra del trabajo sumado de todos los hombres, es completamente legítimo esperar que ese mundo, que ha abierto una realidad confiable, ofrezca las condiciones para desarrollar en él la mejor vida posible para todos los hombres o, de no poderlas ofrecer, permita subvertir su orden para buscarlas.

Obras como la de Grippo alteraban la percepción del orden instituido, cargando la realidad de contenidos dinámicos que alentaban a la transformación de la vida. El carácter dinámico que imprimen a la percepción del mundo constituye la base del acontecimiento del arte, la apertura de espacios donde, como declaró María Teresa Hincapié, uno pueda elegir la existencia que le gusta y formas de vida que le produzcan felicidad.

\section{El borde de un contexto}

El carácter dinámico de la mundanidad y de la existencia que se vive en medio de ésta, ha sido presentado, por la mayor parte de los pensadores de Occidente, como aspecto del cambio de un único mundo en diferentes épocas. Hay que tomar en cuenta ahora que los bordes temporales del sentido llevan implícito un carácter espacial indisociable. El afán de conseguir el alimento significa ganar el tiempo para recorrer las distancias y llevarlo al interior del hogar. Hay que desplazarse de la casa al taller, o a la oficina, o a 
la parcela para traer el sustento. Si bien la obra de arte subversiva amenaza la estabilidad del orden tradicional que los agentes del Estado se esfuerzan en mantener, también desestabiliza la organización espacial, que mantiene a cada uno en su sitio y a cada cosa en su lugar. El existente, caído en el mundo desde su nacimiento, no se establece de modo trascendental, ya que tiene una nacionalidad, una clase social que lo inscribe, habla el idioma y expresa la cultura de un lugar.

La calidez del hogar y el sentimiento de nación existen antes de la construcción de una casa y la fundación de un país. Con ese sentido se abre un claro en el bosque o la selva, se despeja la zona que alberga la construcción. En esto consiste la noción de 'abrir mundo'. Se abre mundo cuando las condiciones espacio-temporales de sentido y acción de la existencia se fundan o se ensanchan. "Sólo si somos capaces de habitar podemos construir" dice Heidegger. Para éste el dejar habitar es la esencia del construir que, a la vez, se completa con el erigir de lugares "por medio del ensamblamiento de sus espacios”.

Al interior del mundo que ha creado el trabajo del hombre hay zonas demarcadas, destinadas para actividades y ocupadas por cosas específicas. El actuar del hombre se circunscribe en un mundo con fronteras espaciotemporales. El hogar está limitado por las paredes y las puertas, la parcela por cercados, los estados por fronteras. La historicidad de la existencia exige que ésta no se conforme con articularse en la apertura ya abierta, es necesario que el acontecimiento de ser se construya también en los hechos que cambian el mundo, en el ámbito de las decisiones y las acciones. La existencia se desplaza en tiempo y espacio, su búsqueda, que imagina y construye nuevas posibilidades de ser, abre el mundo. Pero acontece que pasado un borde espacial el existente es un extraño, un invasor, un extranjero. Se pasa de un mundo a otro mundo, sin cambiar de época, y las posibilidades de ser, pensar y actuar cambian, esta es la condición del extranjero, máxime cuando es indeseable. Para el inmigrante indeseable el mundo abierto, circunscrito dentro de bordes espaciales, se cierra. Si la patria del inmigrante ilegal no ofrece las condiciones de vida suficientes, esto se debe entonces a que allí se cierra el mundo, las cosas, lugares, saberes y acciones no corresponden con sus zonas por insuficientes, por averiadas, por inexistentes.

En agosto de 2005, en la exhibición de arte transfronterizo inSite, Judi Werthein, artista argentina inmigrante legal en Nueva York, presentó la obra llamada 'Brinco'. El proyecto es una intervención en la frontera entre México 
y Estados Unidos que consiste en unas botas diseñadas para ser portadas por los inmigrantes ilegales cuando cruzan de Tijuana a San Diego, equipadas con aditamentos como brújula, linterna, analgésicos, un mapa impreso —en la suela desmontable - con las rutas ilegales más transitadas de Tijuana a San Diego, y símbolos como el águila mexicana y el águila gringa; un bolsillo en la lengüeta para guardar dinero, medicinas u otras cosas que se necesiten durante el viaje, y en la parte posterior la imagen de San Toribio Romo, patrón de los emigrantes (muchos inmigrantes van a rezar a la Iglesia de Santo Toribio Romo, su patrono, antes de brincar).
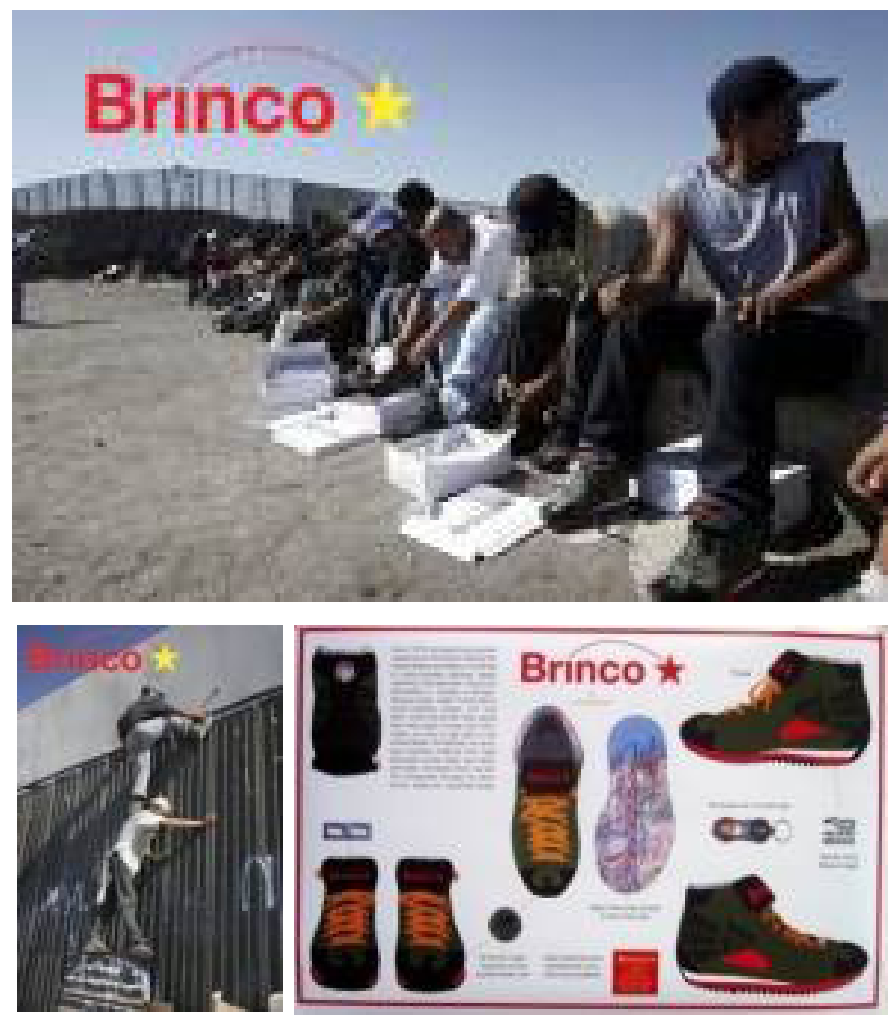

Imagen 12,13, 14, Judi Werthein. Brinco. Intervención, Insite, 2006. Tijuana, San Diego.

Las botas Brinco al tiempo que son una obra de arte, sirven a los inmigrantes ilegales para cumplir una meta de la vida, su uso hace parte de la obra. Las botas son buenos útiles para realizar las tareas de brincar el muro, huir de los guardias fronterizos y los granjeros estadounidenses que les disparan, orientarse, curarse de las heridas, es decir son de confianza para el migrante 
ilegal, cuya existencia es tomada en serio por la artista: "Si van a través de la sierra, caminan ocho horas. Sus pies se lastiman. Hay muchas piedras y hay serpientes y tarántulas. Por eso son pequeñas botas” (Werthein, 2006).

Con el objetivo de preparar la obra y determinar sus componentes, la artista recorrió el duro camino que hacen los inmigrantes ilegales, en condiciones muy favorables: acompañada de la patrulla mexicana y de día. De ese modo pudo conocer las características del terreno que recorren de noche y clandestinamente los ilegales: rocoso, lleno de acantilados, poblado de serpientes venenosas. Como lo resalta Werthein, tal vez el mayor peligro lo representa la Minuteman, asociación de ciudadanos de Estados Unidos que patrullan la frontera de noche con sus rifles y tiran a matar.

Para producir las botas Werthein creó una compañía ficticia llamada 'Brinco' que funcionó con el modelo de otras, contratando, a costos muy bajos, una empresa productora de China. Con la intención de que la obra fuera activa en ambos lados de la frontera, quinientos pares de botas fueron distribuidos de manera gratuita entre personas que tenían planes de atravesar la frontera, en Tijuana, y los otros fueron puestos en venta en una tienda de calzado deportivo en San Diego, por un precio de 215 dólares más impuestos. El sentido de las botas osciló entre útiles confiables para una acción de la existencia para los ilegales de Tijuana, y mercancía suntuaria para ser consumida por compradores de clase media y alta en San Diego.

En Tijuana, las botas hablaban del mundo del 'ilegal' de modo análogo a la obra de Van Gogh analizada por Heidegger, podríamos decir de las botas: "en la oscura boca..." de las botas está grabada la fatiga y el miedo de los pasos veloces del inmigrante, en el ágil y liviano diseño de las botas está prometido el alivio del rápido avanzar mientras ladran los perros de los guardias y la Minuteman a lo largo de los escarpados acantilados. En el hule se estampará la dureza y sequedad del polvo y las rocas del camino a San Diego. En los zapatos tiembla la futura promesa de sustento, el regalo de un trabajo conseguido. A través de este utensilio pasa todo el callado temor por tener seguro el pan, toda la silenciosa esperanza de vencer la miseria, toda la angustia ante el nacimiento próximo y el escalofrío ante la amenaza de la muerte. Este utensilio pertenece a la tierra y su refugio será un mundo prometido al inmigrante.

Las botas en los pies de los inmigrantes tenían valor de uso, al contrario, en San Diego, las botas, constituidas en mercancía, borran las huellas del 
trabajo contratado a bajo costo, las condiciones desfavorables de la vida de los trabajadores que las fabricaron. Si bien una obra de arte es un objeto especial, su carácter originario de cosa permite que sea usada como tal. Según Hans Heinz Holz, la obra, aunque despojada de su magia, puede ser considerada y tratada como una cosa que representa algo, que declara algo, en el modo y manera que representa, sobre lo representado, "Es más, a causa de su función original es un emblema para el rango de su propietario y sigue siéndolo incluso en el caso de que su función original desaparezca en la forma secularizada de una joya [...]”'(Holz, 1972-1979, pp. 14-15). Son botas de 215 dólares más impuestos, mercancías fetiches que, al ser parte de una obra de arte, transfieren un prestigio narcisista a su comprador de San Diego. Sin embargo el comprador lleva las botas junto con una etiqueta que expone con claridad el grado de explotación contenido en la mercancía-botas (cuarenta y dos dólares al mes por una jornada de doce horas diarias de trabajo, la semana completa). Lo recaudado en la venta de las botas se destinó a la Casa del Migrante, un lugar que se dedica a recibirlos cuando llegan a Tijuana y darles un lugar para comer; allí pueden dormir por hasta quince días.

Unas botas, vueltas problemáticas por la intervención artística, conforman un paso de una investigación sobre el mundo, señalan zonas de frontera geográficas, económicas, raciales, que separan existencias. Las botas nos muestran cómo la apertura de mundo a un lado de la frontera, para unos existentes, significa el cerramiento de mundo para existentes al otro lado. Sobre la relación con el espacio había dicho Heidegger que la plástica consiste en "un poner-en-obra que corporeiza lugares y que, con éstos, permite que se abran las comarcas de un posible habitar bumano y las comarcas de un posible permanecer las cosas que circundan y atañen a los hombres" (Heidegger, 2009, p. 33). Las botas abren mundo, allí donde está cerrado, por eso eran confiables para los inmigrantes, y probablemente para algunos de sus compradores de San Diego, pero resultaron dignas de desconfianza para los guardias, los funcionarios y muchos ciudadanos de ambos países, en general para todo aquél convencido y partidario de la forma como funciona la política y el mundo actual. La obra planteó un aspecto funcional que produjo una oscilación particular entre el arte y la vida.

En su condición de obra de arte, Brinco absorbió como partes todos los aspectos de la vida que entraron en juego en el evento, interrumpiendo sus distintas condiciones de familiaridad. "La separación de la realidad empírica que el arte posibilita por su necesidad de modelar la relación del todo y las partes es la que convierte a la obra de arte en ser al cuadrado" (Adorno, 
1983, p. 14), liberando lo vivo de aquello en lo que lo encierra la experiencia exterior y "cosista".

La obra subvertía un orden espacio-temporal asignado a las vidas, que distribuye diferencialmente derechos y privilegios, vigilado y conservado por las instituciones y las corporaciones. Se trata de un sistema de marcas sensibles que descubre la existencia de un común, al tiempo con las delimitaciones que definen los lugares y las partes respectivas, que Jacques Rancière ha llamado 'División de lo sensible': la distribución de "partes y lugares" basada en la división de espacios, tiempos y formas de actividad en la vida común, que a su vez distribuye roles pasivos y activos entre los miembros de una comunidad (Rancière, 2002, p. 3). Con las botas se pone en problema el sistema de sentido dentro del cual unas botas visibilizan las diferencias de derechos de acuerdo al registro del estatus social de los usuarios-consumidores, un paso tortuoso y peligroso que hay que recorrer a pie cuando se es pobre, el uso legitimado institucionalmente de la amenaza de muerte a quien tome la opción de cruzar sin pasar antes por el examen de las embajadas (examen de admisión económico, racial, cultural, político).

\section{Las razones del esfuerzo}

La interrupción artística de las estructuras que nos son habituales puede sacar a la luz estos tipos de estructuras de poder que nos inscriben en registros sociales que interiorizamos como naturales. En la base de la teoría económica, las razones para el esfuerzo, están en relación con las acciones tendientes a solventar la necesidad. El esfuerzo se justifica si está inserto en un proceso de trabajo del que deriven los bienes necesarios para la supervivencia, es decir, cosas útiles. La relación esfuerzo-utilidad se establece bajo la doble condición de que un bien sea necesario y a la vez escaso (al no estar al alcance hay que extraerlo, traerlo de lejos, refinarlo, fabricarlo transformando materia prima, etc.). El esfuerzo requerido para la obtención de un bien determina otra clase de valor, el valor de cambio. Según David Ricardo, si bien la utilidad es absolutamente esencial, la medida del valor de cambio proviene de su escasez y la cantidad de trabajo requerida para su obtención. Este valor está estrechamente vinculado con el concepto de trabajo, tal como fue enunciado por Karl Marx, cuyo pensamiento ha brindado una estructura crítica para abordar la realidad política y económica (si bien la complejidad de las condiciones vitales excede el alcance explicativo de los conceptos del pensador, su estructura fue un paso adelantado en la puesta en evidencia de los fundamentos de la injusticia social cuyas consecuencias saltan a la vista): 
[...] el trabajo es un proceso entre hombres y naturaleza, un proceso en el que, mediante su acción, el hombre regula y controla su intercambio de materias con la naturaleza. Se enfrenta a la materia de la naturaleza como un poder natural. Pone en movimiento las fuerzas naturales pertenecientes a su corporeidad, brazos y piernas, manos y cabeza, para apropiarse de los materiales de la naturaleza en una forma útil para su vida (Marx, 1867, p. 241).

Esta condición determina que sólo el tipo de esfuerzo conducente a la consecución de bienes necesarios que son escasos puede ser considerado como trabajo. El trabajo, visto así, es esfuerzo que se justifica porque de él resultan cosas útiles o valores.

El 11 de abril de 2002, cerca de Lima (Perú), más de quinientas personas se reunieron, convocadas por el artista belga-mexicano Francis Allÿs (con la colaboración de Rafael Ortega y Cuahuctemoc Medina), para correr una montaña usando palas. Al cabo de tres horas la montaña (una duna), había sido corrida en una distancia de dos milímetros, resultado imperceptible pero que por medio de un proceso natural hubiera tardado posiblemente cientos de años y, lo más importante, no tuvo otra utilidad práctica que el hecho de lograr la reunión y la colaboración de tal cantidad de gente. Se trató de una acción artística llamada 'Cuando la fe mueve montañas', planteada dentro del marco de la Bienal de Arte de Lima.
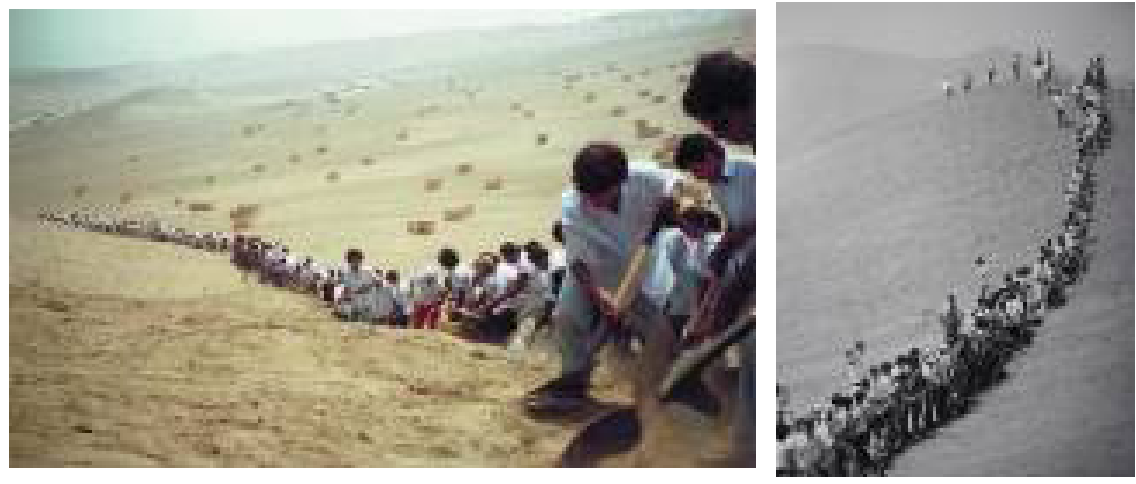

Imágenes 15 y 16. Francis Allÿs. Cuando la fe mueve montañas. Lima, octubre 2000- 11 abril 2002. Registro fotográfico y en video de la acción artística.

La noticia de la obra, que circuló en las crónicas sobre la bienal de arte y también mediante rumores, osciló entre el arte y la política, en un Perú que estaba viviendo el creciente malestar de la última fase del gobierno de 
Alberto Fujimori, instaurado cerca de una década en el poder. Reunirse para mover una montaña ubicada en las afueras de la capital del país podía ser visto como una metáfora de la forma de salir de la crisis. Una obra como esta pone en juego preocupaciones sobre el sentido de las cosas y las acciones humanas: ¿Qué sentido puede tener tanto esfuerzo destinado a una acción sin un resultado productivo, rentable, visible?, ¿por qué los seres humanos invertimos a veces tanto esfuerzo en hacer cosas como éstas? Y en general ¿Por qué esforzarse, ocuparse? Las respuestas más típicas que escucharíamos de cualquiera que se encuentre atareado, esforzándose, serían tales como: porque hay que pagar las cuentas, porque hay que hacerlo, porque al final del trabajo viene el descanso y la gratificación del salario, por la satisfacción de saber que pudimos hacerlo.

Claro que se trataba de un proceso entre hombres y naturaleza, un proceso de apropiación del material de la montaña, desplazando la tierra con la fuerza de muchos cuerpos humanos (brazos, piernas, manos, cabezas), lo que hizo distinto este trabajo de Allÿs es que se trataba de muchas personas colaborando en la realización de una obra de arte 'inútil' en varios sentidos: primero, no habría un resultado objetivado, un producto tangible (hay objetos tangibles de carácter artístico, producto de la actividad de muchas personas, como estatuas, templos, monumentos, lugares turísticos); segundo, no produciría una ganancia objetivable en términos económicos, un bien intercambiable.

Lo concreto en la obra fue el proceso mismo, personas trabajando, desplazando tierra con mucho esfuerzo y concentración. La obra se parecía en ese sentido al trabajo de los labradores con sus parcelas, o de los obreros que abren caminos o allanan terrenos para construir en ellos.
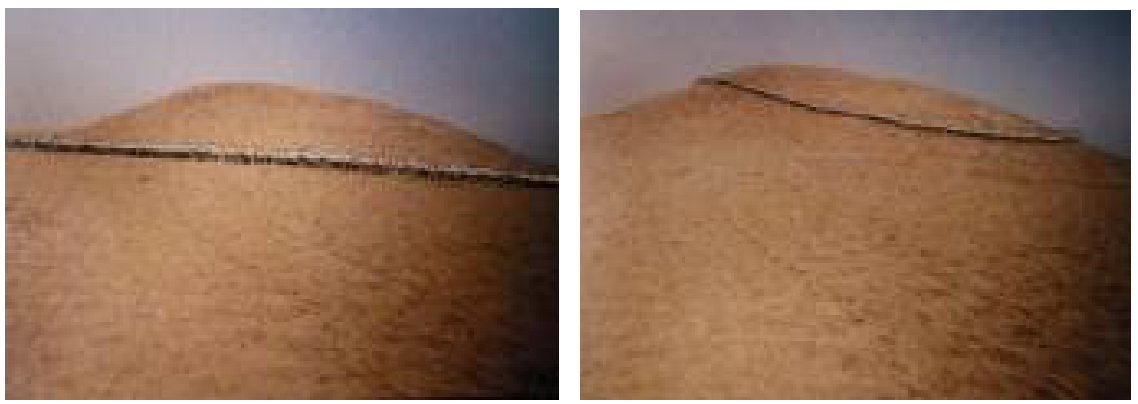


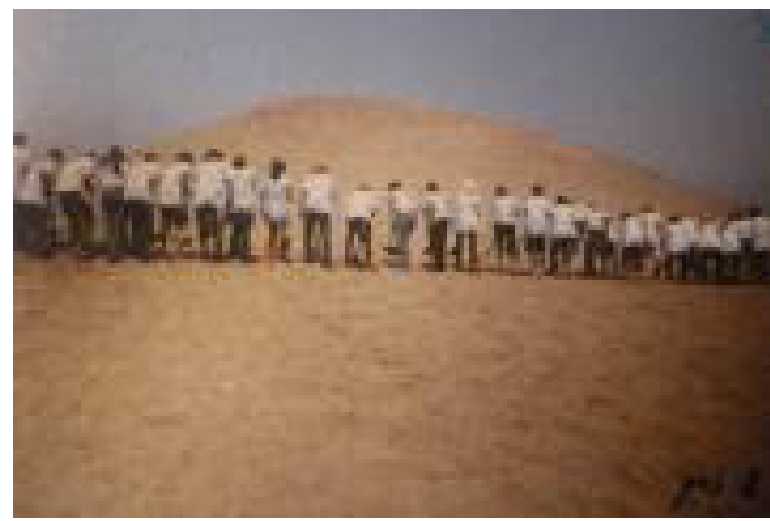

Imágenes 17, 18 y 19. Francis Allÿs. Cuando la fe mueve montañas. Lima, octubre 2000 - 11 abril 2002. Fotogramas de registro en video de la acción artística.

El cambio perseguido y posteriormente operado en la montaña no fue más allá de un desplazamiento de dos milímetros, que por otra parte se hubiera logrado con muy poco esfuerzo, tomando una manotada de tierra de uno de sus extremos para regarla en el otro. Si un proceso de trabajo inicia determinando su objeto (un valor) y se extingue en él, la obra de Francis Allÿs presenta todo el carácter formal de 'trabajo' en el sentido de Marx ${ }^{4}$, pero no corresponde con éste en cuanto a su resultado. Al decir Marx que el trabajo se confunde con su objeto, ya que el trabajo se objetiva en el objeto elaborado, la pregunta por la obra del hombre se asienta en un fundamento de la tradición ética y política de occidente:

Como para el flautista, para el escultor y para todo artesano [technité], y en general para todos los que tienen una obra [érgon] y una actividad [prâxis], lo bueno [tagathón] y el bien [tò eû] parecen [consistir] en esta obra, así debería ser también para el hombre, suponiendo que para él haya algo así como una obra [ti érgon]. ¿O bien [se tendrá que decir] que para el carpintero y el zapatero hay una obra y una actividad, y ninguna en cambio para el hombre, que ha nacido sin obra [argós]? (Aristóteles, 1097 b 22 y ss.).

Siguiendo estos argumentos el ser del trabajador reside, en potencia, y se realiza, en la acción, en el objeto que produce, el flautista, el escultor, el carpintero, el labrador, al objetivar su trabajo en bienes que sirven a la vida humana, cuyos

4 Para Marx, tanto el esfuerzo como el producto son nombrados con el término 'Trabajo': "El uso de la fuerza de trabajo es el propio trabajo". 
valores cambian a la vez por bienes que necesitan para sus vidas, son antes que todo hombres que viven y trabajan. Así la relación entre proceso y resultado requiere elaborarse, desde sus implicaciones con el ser del hombre. La convocatoria con la que el artista buscó reunir el grupo de colaboradores para mover la montaña tenía como consigna "máximo esfuerzo, mínimo resultado", en ella ya estaba implícito que el proceso tendría una relevancia enorme frente a la nimiedad del resultado. Se trataba de un proceso que para desarrollarse exigía mucho esfuerzo de un grupo numeroso de colaboradores, y cuyo resultado sería el grupo mismo y su actividad. Cada uno de los participantes era así 'el hombre que mueve montañas con su fe'. Mover la montaña sirvió para descubrir la fe necesaria para hacerlo, una fe colectiva, la fe del hombre. Luego de la faena, la potencia de hacer, mediante el proceso dinámico, pasaba al ser, en la forma de comunidad cuya fe puede mover montañas. Si el resultado del trabajo es un componente fundamental de la teoría económica del valor, el proceso lo es de la constitución ontológica del hombre.

$\mathrm{Al}$ reconocer el valor fundamental del proceso (del cual posteriormente derivaría el producto) el mismo Marx necesitó apuntalar sus tesis económicas en fundamentos ontológicos. Para éste la producción de valores de uso no cambia su índole más general al interior de una forma social específica (por ejemplo la explotación y control capitalista). En su sentido más general, durante el proceso el trabajo "cambia constantemente de la forma dinámica a la del ser, de la de movimiento a la de objetividad" (Marx, 1867, p. 256). Este cambio de naturaleza arrastra consigo:

1. Al esfuerzo y la actividad humana, que se convierten en trabajo, obra del hombre conducente a la concreción de la potencia natural en bienes que sirven a la vida humana. El hombre, en tanto trabajador, "se convierte en fuerza de trabajo en acción, en obrero, lo que antes sólo era en potencia" (Marx, 1867, p. 241).

2. Al hombre mismo, al arrancarlo de su condición de animal que sobrevive y conducirlo a animal que labora. Esta diferenciación está condicionada tanto por su forma como por la finalidad. Porque el proceso del trabajo exige el esfuerzo del pensamiento, el aprendizaje de habilidades, la determinación de metas y la anticipación del resultado mediante un proyecto.

3. A la materia elaborada por el trabajo, que ingresa a la modalidad de producto con valor (de uso y de cambio) para la vida humana. El valor 
que el trabajo comunica a su objeto queda depositado en éste. Porque el valor de los productos no es consumido todo de forma inmediata se hace posible, primero, intercambiarlos como mercancía por otros bienes con valor equivalente y, segundo, ponerlos a disposición de necesidades futuras, almacenándolos. El trabajo convierte a la naturaleza en fuente de emancipación, de la premura de la escasez, para la vida humana. Al final del trabajo, "lo que en el trabajador era dinamismo, se presenta abora en el producto como quietud, en la forma del ser” (Marx, 1867, p. 245). Así, el trabajo, como paso de potencia a dinamismo, termina en la producción del ser libre en el producto que permite el descanso.

4. A la vida humana, cuya finalidad es arrancada de la sola conservación y se convierte en vida libre. La quietud final, que en el producto obtiene su ser, no implica para Marx la inactividad sino la actividad liberada de la necesidad. El proceso del trabajo, y sólo él, produce libertad.

El trabajo, según esto, es la potencia específica que al pasar a la acción ha producido una mutación esencial en el hombre, lo ha separado de todas las otras especies, para constituirlo en el (único) animal que trabaja. En la argumentación marxista está implícito, aunque no resaltado de modo central, que el resultado fundamental del trabajo, visto en tanto proceso global, independiente de los productos específicos, es la posibilidad de la vida libre como vida auténticamente humana. La fe del hombre, que cambia la forma de la naturaleza, adaptando el material a las necesidades de su vida, tiene como producto más originario la constitución de sí mismo como miembro de una comunidad libre. Una comunidad con fe en sí misma. Una comunidad cuya fe le hace capaz de mover montañas si es preciso. El cambio ontológico operado en el paso de la escasez a la forma dinámica y de ésta a la de ser libre, ayuda a establecer el sentido más fuerte presente en la obra sin objeto, la constitución de la ontología del hombre mismo.

Gran parte de las obras de Francis Allÿs dejan como producto su registro, rumores que circulan, y huellas del proyecto mismo. Planteando la futilidad del esfuerzo productivo y económico (afán de generar valor de cambio), recupera al tiempo la mirada hacia la esperanza o la desesperanza del modo de vida actual. En la obra 'Paradoja de la praxis' Allÿs presenta un registro en video de su recorrido por Ciudad de México, empujando con bastante esfuerzo un bloque de hielo que paulatinamente va derritiéndose hasta desaparecer, acompañando con su acción el transcurrir de un día cualquiera de la ciudad, y cruzándose esporádicamente con la mirada curiosa o la indiferencia de los transeúntes ocupados de sus asuntos. 

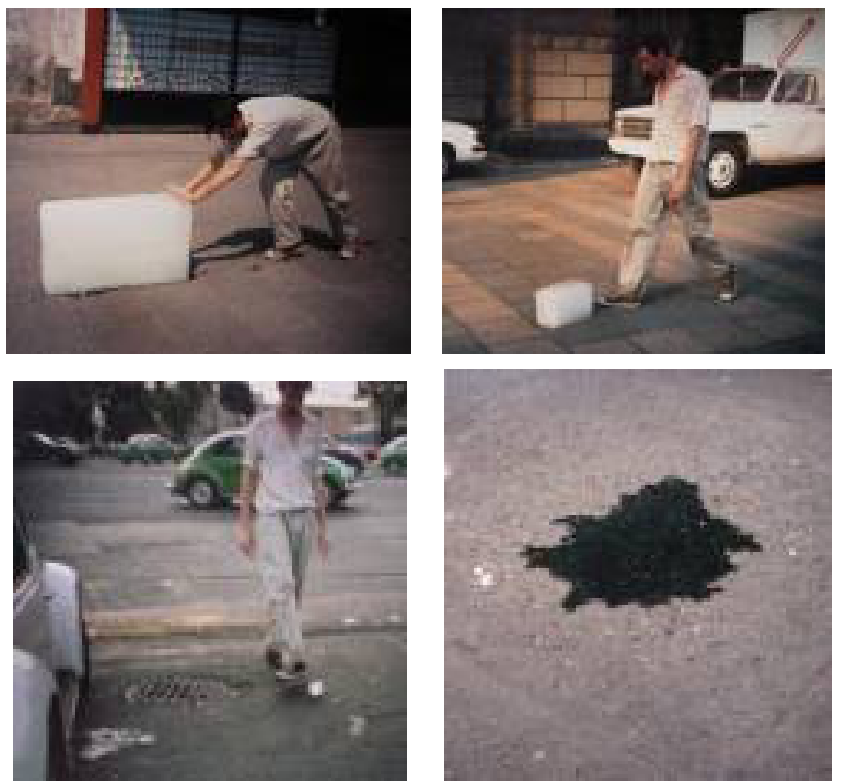

Imágenes 20, 21, 22 y 23. Francis Allÿs. Paradoja de la praxis. Algunas veces hacer algo no lleva a nada. México D.F., 1997. Acción registrada en video.

$\mathrm{Al}$ poner en juego un proceso sin producto, la obra de Allÿs ha adoptado algunos rasgos formales ya vigentes en el arte desde la segunda mitad del siglo XX, como la desvirtuación del producto objetual de la obra, problema central en el Arte Conceptual; la reducción del carácter material y manual del trabajo artístico, fundamento del Minimal Art; y la exaltación protagónica del proceso mismo, ya sea como investigación o como elaboración (llevada a espacios exhibitivos mediante documentos o registros del proceso), postulado central del llamado Arte de Proceso, consolidado a partir de la década de 1970. Allÿs radicaliza en su obra varios de estos rasgos, denominando sus prácticas 'ensayos' (en el sentido, usado en teatro o danza, de prueba anterior a la presentación final de una obra). En los ensayos de Allÿs queda permanentemente pospuesta la culminación. Si, como queda expuesto en el concepto de trabajo de Marx, el proceso del trabajo humano se diferencia del de los animales en que al final se obtiene un producto que existía ya al comienzo en la imaginación del obrero en forma ideal, y logrado este ideal lo que en el trabajador era dinamismo, se presenta ahora en el producto como quietud, el 'ensayo' rompe el ciclo en sus extremos. El ensayo no ha sido configurado a priori como producto ni tampoco llega a final como producto. 
El ensayo no conduce a la quietud prometida en el producto. Las obras postergadas en el ensayo de Allÿs, afirma el curador de la exposición del artista en Bogotá ${ }^{5}$, siempre pueden cambiarse, aumentando su potencial para nuevas reconfiguraciones, se proyectan a una forma final siempre futura y nunca presente. La obra "puede revisitarse constantemente, y su presencia puede cambiar permanentemente de forma, no sólo como documentación con fotografías o video, sino también por medio de descripciones escritas o recuentos orales trasmitidos de boca a boca" (Ferguson, 2009). Cada nueva presentación de la obra, y también cada nuevo encuentro del público con un ensayo de Allÿs genera nuevas reacciones y conclusiones, y abre así el horizonte del arte a la participación productiva y no solamente a la contemplación o juicio. La obra vuelve a ser configurada con cada descripción o apropiada mediante el rumor que establece nuevos intereses y sentidos. La obra produce posibilidades en la medida en que el no cierre se articula con el carácter participativo y colaborativo, cuyo responsable y autor no es el artista sino el colectivo del público, presente o posible.

Según Toni Negri el fruto que brota del conjunto del trabajo humano acumulado, que determina valores y excedencias, es un hecho creativo, cuyo valor más construido y universal, al tiempo que el más singular es el arte, comunidad (multitudo ${ }^{6}$ ) en el acto (Negri, 2000). Por lo tanto el artista que obra a partir de la colectividad se beneficia del producto y el conocimiento de la especie y a la vez su logro se revierte a las necesidades y las preocupaciones de todos los demás hombres. La completación de un ensayo es obra colectiva, su potencia no viene dada por el artista sino que se produce en el colectivo conformado por sus colaboradores y su público. La producción de una obra verdaderamente colectiva exige la retirada del protagonismo del artista como autor o enunciador de sentido, en beneficio de la expresión de una comunidad.

Varios aspectos de la relación entre valor, trabajo y existencia aparecen en la representación y exposición que hace el artista Alfredo Jaar en la obra 'Rushes'. La obra presenta impresiones de alta resolución de fotografías, tomadas por el artista, de situaciones del trabajo de buscadores de oro brasileños, yuxtapuestas a carteles que anuncian la cotización del precio

5 Francis Allÿs, política del ensayo. Exposición curada por Russell Ferguson y realizada en 2009 en la Biblioteca Luis Ángel Arango de Bogotá.

6 El editor del texto incluye la aclaración de Negri sobre el término 'Multitudo', que evita el carácter despectivo que ha tomado 'Multitud' y busca denotar el sentido más spinozista, según el cual la democracia es la acentuación máxima de la actividad creativa de una "multitud rica". 
del oro en la bolsa, todo esto instalado en las paredes de la estación Spring Street del metro de Nueva York. Los transeúntes y pasajeros del metro se encontraban así con los dos extremos del proceso del oro, su producción y su valoración. Estos extremos ponen en percepción la escasez evidente de bienes de uso en la vida de los trabajadores en contraste con la exposición de una cifra que representa la riqueza representativa derivada del producto de ese trabajo.
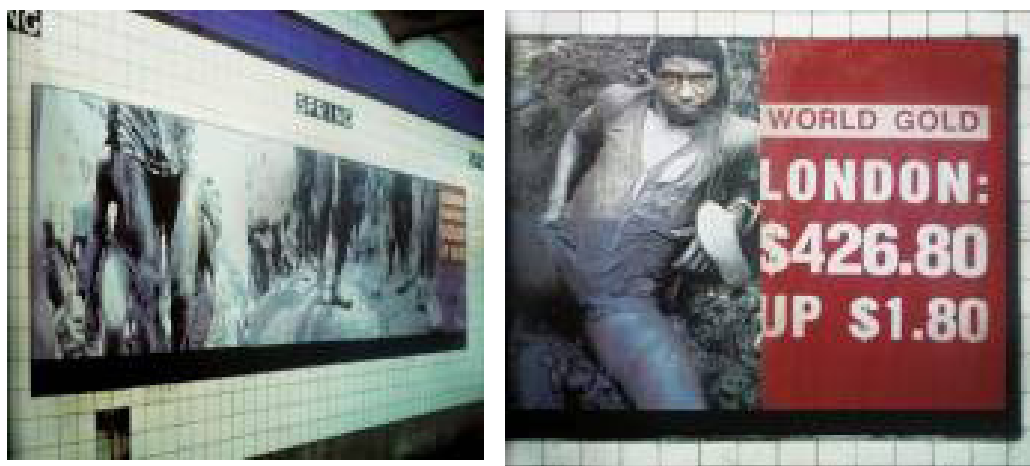

Imágenes 24 y 25. Alfredo Jaar. Rushes, 1986.

Porque el oro es una mercancía especial que también funciona como patrón de medida del valor, el valor del oro, expresado en la cantidad de dinero por la cual podría ser cambiado, es ejemplo paradigmático de mercancía fetiche. La condición humana, abierta en la naturaleza por la actividad del hombre y para posibilitar su acción, constituye relaciones entre cosas y hombres que producen diferenciaciones derivadas de la utilidad y el valor. Los bienes, producidos por el trabajo, están disponibles mediante la adquisición compensatoria de su valor en el mercado, en la modalidad de mercancías. Según el análisis de Marx, considerada bajo el punto de vista del existente, una mercancía satisface con sus propiedades necesidades humanas, o recibe estas propiedades como producto del trabajo humano (Marx, 1867); pero desde el punto de vista del mercado estas propiedades se pierden de vista, haciendo aparecer de manera casual el valor de cambio como su propiedad determinante. En una mercancía no hay nada misterioso en cuanto a su valor de uso, su carácter místico emerge al convertirse en mediadora y señal de diferencias entre ámbitos sociales, cuando su valor transfiere un estatus especial a su poseedor. La mercancía fetiche "no es más que la relación social determinada de los mismos hombres, la cual adopta aqui la forma fantasmagórica de una relación entre cosas” (Marx, 2000, p. 103). 
En el mismo año Jaar presentó para la Bienal de Arte número 42 de Venecia 'Gold in the morning', una instalación de cajas de luz con fotografías en transparencias de los mineros, junto a marcos y clavos dorados que aluden al oro. En ambas obras el contexto internacional de su presentación insertaba su sentido en los flujos del arte y la economía mundial.
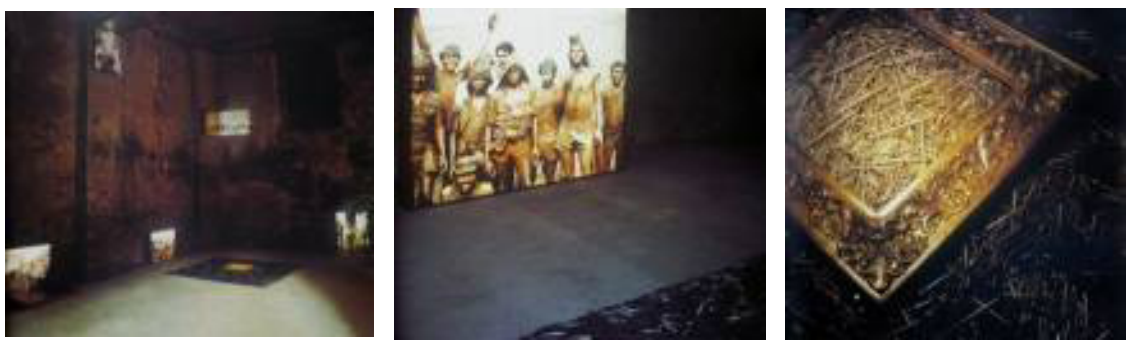

Imágenes 26, 27 y 28. Alfredo Jaar. Gold in the morning, 1986.

Ya que el oro se estableció en muchas culturas como patrón representativo del trabajo requerido para su extracción, salvo en ocasiones muy particulares, el oro (en cualquier forma) tiene un valor de cambio prácticamente absoluto en comparación con su valor de uso restringido. Planteó Marx que este carácter fetichista de la mercancía está determinado por un valor de cambio que oculta en el secreto el valor del tiempo de trabajo. Si bien la puesta en evidencia puede eliminar la apariencia de la determinación puramente casual de las magnitudes de valor de los productos del trabajo, no elimina en absoluto su forma objetiva, su valor de uso y su valor derivado del proceso de trabajo (Marx, 2000, p. 103). Pero en el caso del oro, no salta a la vista ninguna forma objetiva, ningún valor de uso más que la posibilidad de cambiarlo por los bienes de uso escasos en la vida de los extractores de oro (comida, medicina, ropa, vivienda). Las vidas de los mineros se presentaban en las obras como un valor vital que hace ruido al valor de cambio de la riqueza abstracta que representa el oro.

Las obras dejan en el ambiente la pregunta de quién se ha quedado con el valor de cambio que ha ganado el oro en los mercados, si es evidente que no han sido los trabajadores. La abrumadora distancia entre la riqueza representada por el producto y la precariedad de condiciones de vida y trabajo de los obreros puede abordarse inicialmente a partir de la noción de enajenación, postulada por Marx como fundamento de la explotación. La enajenación, según Marx, consiste en que el trabajo no pertenece al ser del trabajador, es 
externo. Junto con la materia prima y los medios de producción, el proceso de trabajo es consumido en el proceso de valoración, de ese modo la vida del trabajador entra al cálculo del gasto y de la ganancia. La enajenación, según Marx, consiste en que el trabajo no pertenece al ser del trabajador, es externo. "El trabajador se convierte en una mercancía tanto más barata cuantas más mercancías produce. La desvalorización del mundo bumano crece en razón directa de la valorización del mundo de las cosas” (Marx, 1844, p. 66). En la medida en que el proceso de consumo produce y requiere la enajenación de la actividad y la fuerza productiva del trabajador, que se convierte en una mercancía barata, cuantas más mercancías produce (Marx, 1844), todo el esfuerzo y las penurias invertidos por los mineros en la extracción del oro representan para ellos la translación de valor mínimo a sus vidas, ni siquiera lo necesario para sacar de allí el sustento.

La actividad laboral, al margen de las circunstancias históricas o sociales, de la durabilidad de sus productos, posee una 'productividad' suya, y dicha productividad, afirmó Hannah Arendt, "no se basa en los productos de la labor, sino en el 'poder' bumano, cuya fuerza no queda agotada cuando ba producido los medios para su propia subsistencia y supervivencia, que es capaz de producir un 'superhábit', es decir, más de lo necesario para su propia 'reproducción'” (Arendt, 1958, p. 103). Aquí se expresa un principio central de la crítica a la injusta repartición de la riqueza, que el consumo de fuerzas requeridas por el trabajo debe compensarse con la obtención de un superhábit que mejore las condiciones de la vida del trabajador, es decir, que nuestro trabajo produzca más de lo que consumimos para realizarlo. Pero el consumo capitalista arranca las fuerzas productivas del individuo, que ahora aparecen como completamente independientes (Marx \& Engels, 1970), y esto sale a la luz con la obra de Jaar, que las fuerzas vitales del trabajador producen una gran cantidad de riqueza que no llega a suplir la escasez para su propia vida.

En cuanto componente del proceso de valor, la vida del capitalista también se ve enajenada, ya que él mismo no es más que capital personificado cuyo único instinto vital es valorizarse, crear plusvalía, absorver los medios de producción y la mayor masa posible de plustrabajo. Esto se debe a que el capitalista, en calidad de comprador del tiempo y fuerza del obrero, "procura extraer la mayor utilidad del valor de uso de su mercancía” (Marx, 1867, p. 312). Al interior de la lógica de la ganancia, durante el tiempo comprado al 
trabajador, el capitalista consume su fuerza de trabajo, pero el tiempo que el obrero consume para vivir debe robárselo al capitalista.

Escriben Deleuze y Guattari que el problema fundamental de la filosofía política sigue siendo el planteado por Spinoza y descubierto por Wilhelm Reich: "¿por qué combaten los hombres por su servidumbre como si se tratase de su salvación?” (Deleuze \& Guattari, 1972-1985, p. 36). La fuerza enajenadora de los procesos de valor económico tiene el poder de arrazar toda otra forma de valor vital y absorve la experiencia en vectores abstractos de cálculo de ganancia. Como lo expresaron Deleuze y Guattari "en el centro del Capital Marx muestra el encuentro de dos elementos principales: "de un lado el trabajador desterritorializado, convertido en trabajador libre y desnudo, que tiene que vender su fuerza de trabajo; de otro, el dinero descodificado, convertido en capital y capaz de comprarla" (Deleuze \& Guattari, 1972-1985, p. 232). Por eso el capital se vuelve filiativo, el dinero sólo engendra dinero. El consumo económico de las fuerzas de la vida de los sujetos implicados en él termina produciéndose y reproduciéndose a sí mismo, consumo que sólo produce consumo. El universo del consumo, según Jean Baudrillard, es un sistema de socialización basado en la manipulación sistemática de signos, una práctica idealista en la que los sujetos se constituyen con base en objetos que median y rigen sus identidades. El problema del ser se oculta en la habitualidad social del consumo, pero la ocultación del problema reclama un sentido que no es llenado sino temporalmente suspendido en la espiral consumista (producción-adquisición-uso-obsolescencia-descarte). La suspensión de la pregunta exige su ocultación mediante redundancias de sentido como las que ofrecen los discursos publicitarios ${ }^{7}$ (exageraciones de éxito sexual, de aceptación social, de triunfos afectivos), redundancias que funcionan en las representaciones publicitarias pero que nunca se consuman en la vida. La posesión del consumo no terminará nunca porque nunca se consuma su promesa. La suspensión de la pregunta no significa una ganancia ni un alivio sino un déficit que va siendo suplido (y nunca llenado) por la acumulación y descarte sucesivos que le someten a procesos inacabables de adquisición de productos de un mercado en permanente actualización.

Si la habitualidad consiste en la ocultación de la problematicidad de las cosas, lo que se produce en la obra de arte es un 'estado de no ocultación' que Heidegger presenta con el término griego 'Aletheia' (fuerza de la verdad):

7 Dice Baudrillard: Siempre se instala algo redundante allí donde no hay nada. 
"Verdad significa esencia de lo verdadero. Pensamos la verdad recordando la palabra que usaban los griegos. Aletheia significa el desocultamiento de lo ente"(Heidegger, 2005a, p. 36). La desocultación, más que un estado existente, es el acontecimiento artístico por excelencia. Si lo que acontece en la obra es la desocultación de un problema, éste es de la verdad. La verdad acontece en la obra de arte al hacer aparecer la problematicidad, la 'instalación' de la oposición entre 'alumbramiento' de la mundanidad abierta por el hombre, y la 'ocultación' del carácter esencialmente misterioso de la potencia de vivir que resiste en su interior en la forma de naturaleza.

La noción 'obra del hombre', principio central del pensamiento político y ético de los griegos antiguos, ha recorrido una larga tradición en el pensamiento occidental. Según la argumentación aristotélica, la finalidad de cada trabajo específico es un bien que le es propio, consistente en el producto de dicho obrar, así el producto del obrar colectivo del género humano debe consistir en un bien supremo, y éste es la felicidad. La virtud que puede ser practicada por un individuo, sólo realiza su potencia plena en la medida en que expresa la multitud (el concepto de 'obra del hombre', en su sentido más general, se mantiene como fundamento del concepto de trabajo en Karl Marx). El arte contemporáneo de Latinoamérica se ha desarrollado en medio de intentos de circunscribirlo en matrices del arte internacional desarrollado en los centros económicos y culturales, y desde una realidad política compleja, llena de contradicciones y vacíos que afectan las posibilidades de su alcance o su fe en sí mismo. La capacidad de presión del mercado sigue alterando los flujos de la vida, del trabajo, del pensamiento, con matices variables en la mayor parte de los países latinoamericanos.

En la obra 'Cámera Lúcida', comisionada para inaugurar el museo de arte del oeste de Caracas, Alfredo Jaar enfrentó la pregunta sobre el carácter y relevancia de una obra de arte que abriría la presencia del museo en un sector periférico y popular de una ciudad latinoamericana. La opción tomada por Jaar fue distribuir mil cámaras fotográficas entre los habitantes del sector, para que fueran ellos quienes constituyeran un corpus de imágenes que mostraran, además de las cosas y lugares que conformaban sus vidas cotidianas, sus modos propios de mirar. Consecuente con la noción de 'Cámara lúcida' de Roland Barthes, el artista hacía a un lado su modo de mirar para suscitar la autorrepresentación de la comunidad. El carácter procesual y documental de esta obra ponía así en cuestión la autoría colectiva del arte. De nuevo se trató del arte corriéndose a un lado para dejar ver la vida. 

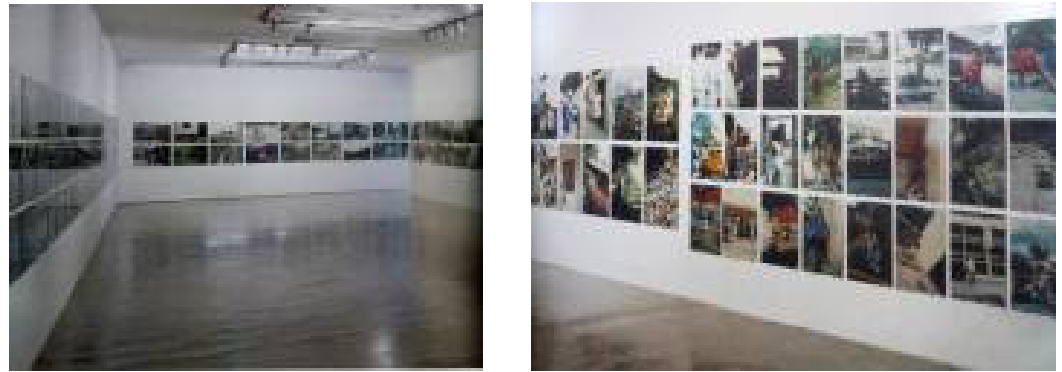

Imágenes 29 y 30. Alfredo Jaar. Camera Lúcida. Caracas, 1996. Montaje con fotografías. Museo del oeste de Caracas.

El carácter del arte, resalta Luis Camnitzer, dada la intensidad de la carga política que tiene la vida cotidiana en Latinoamérica, termina siendo político y no sorprende que tantas veces "refleje esta tensión, y que a veces sobrepase los intereses concretos que uno espera de las definiciones tradicionales del arte" (Camnitzer, 2008, p. 33). En la frase de Alfredo Jaar "Yo me dedico al mundo, a lo que está fuera del ámbito del arte" se plantea la retirada del artista creador para dar paso al artista suscitador, expresando el principio de obra colectiva que sustenta, en sus fundamentos y en su finalidad, el obrar humano. Las definiciones de lo que es arte no han salido inmunes al potencial expresivo y político que obras como la de Jaar han insertado en sus exhibiciones, colecciones y museos. Esta mutación, tal como es anunciada por Jacques Rancière, alcanza el concepto de Obra del hombre al reclamar la entrada de la experiencia sensible y la expresión de las comunidades y los seres sometidos al borramiento por la élite de la economía y la cultura: "El museo del futuro debe responder a imperativos de integración, de reconocimiento de las capacidades de todos. $Y$ debe al mismo tiempo sorprender las expectativas de quienes lo visitan y contribuir con el choque de la experiencia a formar un sensorium diferente. El sensorium del arte es siempre un 'sentido común' paradójico, un sentido común disensual, becho de acercamiento y de distancia (Rancière, 2005, p. 79)" .

La aparición de un sentido común paradójico e incluyente promueve nuevas espacialidades y hace tambalear las fronteras sensibles que han separado el gusto y la creatividad de la vida de todos, de las experiencias refinadas reservadas de las clases dominantes. Para Deleuze el sentido no existe sino que insiste o subsiste en la línea fronteriza, donde ya no hay solamente efectuación, sino emergencia del acontecimiento. Como lo propone el filósofo, el sentido puede definirse como "lo percibido tal como aparece en presencia”, una unidad objetiva que funciona como correlato intencional del 
acto de percepción (Deleuze, 1989, p. 43). Por eso no debemos preguntar cuál es el sentido de un acontecimiento ya que el sentido se da en el acontecimiento mismo, el acontecimiento no habla, como tampoco se habla de él. Está por verse si el lugar del acontecimiento del disenso sea el museo, o si el arte reclama los espacios de la vida, precisamente para señalar su existencia y su sentido. Si el museo emerge con nueva potencia en el momento en que acontece el arte, pero en ausencia de éste no es más que un espacio que sirve para otra cosa. El artista y el museo aparecerían como suscitadores de visibilidad de emergencias creadoras que saben retirarse para dejar ver y acontecer la vida. Entonces la historia del arte no comienza en las pinturas de las cavernas sino con las vasijas, las hachas de piedra, las puntas de flecha.

\section{Referencias}

Adorno, T. W. (1970-1983). Teoría estética (2 ed.). Riaza, F. (trad.). Barcelona: Ediciones Orbis.

Agamben, G. (1998) El hombre sin contenido. Margaretto Kohrmann, E. (trad.) Barcelona: Ediciones Áltera.

Agamben, G. (2007). 'La obra del hombre'. Agamben, G. La potencia del pensamiento (pp. 465-480). Buenos Aires: Adriana Hidalgo Editora.

Allÿs, F. Paradoja de la praxis. Algunas veces hacer algo no lleva a nada. México D.F.

Arendt, H. (1958-1993). La condición bumana. Barcelona: Paidos.

Camnitzer, L. (2003). ‘'Arte y vida?’ C. d. Lam, 8 Bienal de La Habana. El arte con la vida (pp. 31-37). La Habana: Centro de arte contemporáneo Wilfredo Lam.

- (2008). Didáctica de la liberación. Arte conceptualista latinoamericano. Montevideo: Casa editorial HUM.

Deleuze, G. (1989). Lógica del sentido. Barcelona: Paidós.

Deleuze, G., \& Guattari, F. (1972-1985). El antiedipo. Capitalismo y esquizofrenia (2 ed.). Monge, F. (trad.) Barcelona: Paidós.

Federici, C. (2002). 'Algunos aportes relativos al problema de la investigación'. Trans $N^{o}$ 2. Investigación: palingenesia de saberes (2), 8-13.

Ferguson, R. (mayo-agosto de 2009). Francis Allÿs, política del ensayo. (Biblioteca Luis Ángel Arango), González, G. (ed. y trad.). Bogotá. 
Guattari, F. (1993). 'El nuevo paradigma estético'. Guattari, F. El constructivismo guattariano (pp. 75-94). Cali, Colombia: Centro editorial Universidad del Valle.

Heidegger, M. (2001). 'La pregunta por la técnica'. Heidegger, M. Conferencias y artículos. Barjau, E. (trad.) (2 ed.) (pp. 9-32). Barcelona: Ediciones Del Serbal.

- (2005a). 'El origen de la obra de arte'. Heidegger, M. Caminos de bosque. Cortés, H. \& Leyte, A. (trads.) (pp. 11-62). Madrid: Alianza editorial.

(2005b). 'La época de la imagen del mundo'. Heidegger, M. Caminos de bosque. Cortés, H., \& Leyte, A. (trads.) (4 ed.) (pp. 63-90). Madrid: Alianza editorial.

_ (2006). Ser y tiempo. Rivera, J. E. (trad.) (3 ed.). Madrid: Trotta.

— (2009). 'El arte y el espacio'. Heidegger, M. Barcelona: Herder editorial.

Hincapié, M. T. (1990). Texto complementario al montaje de la obra "Una cosa es una cosa”.

- (2002). María Teresa Hincapié: Amó mucho la libertad y el riesgo. González, O. J. (entrevistador).

Holz, H. H. (1972-1979). De la obra de arte a la mercancía. Barcelona: Gustavo Gili.

Llanes, L. (2004). 'Un acercamiento a la obra de Víctor Grippo en la Quinta Bienal de La Habana'. Pacheco, M. Grippo una retrospectiva. Obras 1971-2001 (pp. 39-47). Buenos Aires: Fundación Eduardo F. Costantini/ Malba - Colección Costantini.

Marx, K. (1844). 'Trabajo enajenado'. Marx, K. Manuscritos económicos y filosóficos de 1844 (pp. 65-82). Santiago de Chile: Empresa editora austral.

- (1867). El capital. Romano García, V. (trad.) (2 ed. Vol. 1). Madrid: Akal.

Marx, K., \& Engels, F. (1970). La ideología alemana. Barcelona: Grijalbo.

Negri, T. (2000). 'Carta a Massimo, sobre lo bello'. Negri, T. Arte y multitudo. Ocho cartas (pp. 50-56). Madrid: Trotta. 
Pabón, C. (2000). 'Actos de fabulación. Arte, cuerpo y pensamiento'. Colombia, M. D. \& Gaitán, A. (Ed.). Proyecto Pentágono. Investigaciones sobre arte contemporáneo en Colombia (1 ed.) (pp. 67-114). Bogotá: Imprenta Nacional de Colombia.

Rancière, J. (2002). La división de lo sensible. Salamanca: Centro de arte de Salamanca.

(2005). Sobre políticas estéticas. Barcelona: Museu d'art contemporani de Barcelona y Servei de publicacions de la Universitat Autónoma de Barcelona.

Rodríguez, H. M. (2003). 'Una bienal cifrada en la esperanza'. C. d. Lam, 8 Bienal de La Habana. El arte con la vida (pp. 21-30). La Habana: Centro de arte contemporáneo Wilfredo Lam.

Werthein, J. (2006). Las polémicas Brinco. A. Cúpula (Entrevistador). Recuperado de http://www.parati.com.ar/nota.php?ID=8140

Wittgenstein, L. (1918). Tractatus lógico-philosophicus (Vol. 1). (Muñoz Veiga, J. \& Reguera Pérez, I. (trads.). Madrid: Gredos. 